\title{
Cultured ruminal epithelial cells express a large-conductance channel permeable to chloride, bicarbonate, and acetate
}

\author{
Friederike Stumpff • Holger Martens • Sabine Bilk • \\ Jörg R. Aschenbach • Gotthold Gäbel
}

Received: 16 June 2008 / Accepted: 26 July 2008 /Published online: 21 August 2008

(C) Springer-Verlag 2008

\begin{abstract}
The absorption of short-chain fatty acids (SCFA) from the rumen requires efficient mechanisms for both apical uptake and basolateral extrusion. Previous studies suggest that the rumen expresses a basolateral chloride conductance that might be permeable to SCFA. In order to characterize this conductance in more detail, isolated cultured ruminal epithelial cells were studied with the patch-clamp technique, revealing a whole-cell conductance with $p\left(\mathrm{Cl}^{-}\right) \approx$ $p\left(\mathrm{NO}_{3}{ }^{-}\right)>p\left(\mathrm{HCO}_{3}{ }^{-}\right)>p\left(\right.$ acetate $\left.^{-}\right)>p\left(\right.$ gluconate $\left.{ }^{-}\right)$. Currents could be blocked by diisothiocyanato-stilbene-2,2'-disulfonic acid ( $1 \mathrm{mmol}^{-1}>100 \mu \mathrm{mol} \mathrm{l^{-1 }}$ ), 5-nitro-2-(3-phenylpropylamino)benzoic acid $\left(50 \mu \mathrm{mol} \mathrm{l^{-1 }}\right)$, niflumic acid $(100 \mu \mathrm{mol}$ $\left.\mathrm{l}^{-1}\right)$, and $p$-chloromercuribenzoate $\left(1 \mathrm{mmol} \mathrm{l}^{-1}\right)$. Singlechannel conductance was $350 \pm 7 \mathrm{pS}$ for chloride and $142 \pm$ $7 \mathrm{pS}$ for acetate. Open probability could be fitted with a threestate gating model. We propose a role for this channel in mediating the permeation of chloride, bicarbonate, and acetate across the basolateral membrane of the ruminal epithelium.
\end{abstract}

Keywords Rumen · Chloride channel · Acetate · Short-chain fatty acid $\cdot$ Bicarbonate $\cdot$ Patch-clamp

\section{Introduction}

Microbial breakdown of carbohydrates leads to accumulation of short-chain fatty acids (SCFA) in the gut of man and

F. Stumpff $(\bowtie) \cdot$ H. Martens

Institut für Veterinär-Physiologie, Freie Universität Berlin, Berlin, Germany

e-mail: stumpff@zedat.fu-berlin.de

S. Bilk · J. R. Aschenbach • G. Gäbel

Veterinär-Phyiologisches Institut, Universität Leipzig,

Leipzig, Germany animals, reaching levels of 100 to $180 \mathrm{mmol} \mathrm{kg}^{-1}$ in the colon of monogastric mammals [1-3], with similar values of 60-150 mmol $\mathrm{l}^{-1}$ having been measured in the rumen of cows and sheep [4]. Despite the importance of an effective absorption of these energy-rich substrates from the gut in the interest of nutrition and intestinal health, our knowledge of the mechanisms of transcellular absorption continues to be incomplete [3]. In particular, we know little about the mechanisms of basolateral extrusion $[3,5]$.

Attributable undoubtedly in part to its tightness and availability, the rumen was the first tissue in which the transcellular transport of SCFA was investigated [3, 6, 7]. The importance of the undisturbed metabolism of SCFA for the health and performance of ruminants can hardly be overestimated, with their production in cattle reaching more than $100 \mathrm{~mol} /$ day and accounting for more than $75 \%$ of the total metabolizable energy in these animals [5, 8, 9]. Most of the SCFA are absorbed by the ruminal epithelium [10-12], and although a large fraction of butyrate is metabolized intracellularly [4, 13-15], both in vivo [14-16] and in vitro studies [17-21] have demonstrated that considerable amounts of acetate and propionate cross the basolateral membrane of the rumen in an unmetabolized state.

Cell homeostasis demands that transcellular SCFA transport must be accomplished in a manner that maintains intracellular $\mathrm{pH}$ and cellular volume. In light of the high levels of SCFA that are found physiologically in the rumen, with concentrations of acetate alone reaching values of over $70 \mathrm{mmol}^{-1}$ [4], a simple epithelial model with efflux via lipid diffusion cannot meet these requirements ([22, 23] and Appendix). Conversely, monocarboxylate transporters can mediate the efflux of sizable amounts of SCFA at neutral values of cytosolic $\mathrm{pH}$ because of their ability to bind protons, and recent studies support a role for monocarboxylate transporter 1 (MCT1) in the basolateral efflux of monocarboxilic acids from the rumen [21, 24, 25]. 
However, since the transporter is electroneutral, the driving force for efflux relies exclusively on the accumulation of SCFA within the cytosol, suggesting that additional pathways are necessary.

From a teleological point of view, the utilization of the considerable blood-side positive electrical gradient for the extrusion of the SCFA anion via an electrogenic pathway appears an efficient and workable alternative that would greatly enhance the ability of the ruminal epithelium to transport SCFA without endangering cellular $\mathrm{pH}$ regulation and volume control. In the light of mounting evidence supporting the existence of a basolateral chloride conductance in the rumen [26-28], we wanted to know whether isolated ruminal epithelial cells express anion channels permeable to acetate. Our data demonstrate a large anion channel of $350 \pm$ $9 \mathrm{pS}$ in symmetrical $130 \mathrm{mmol} \mathrm{l}^{-1}$ chloride solution, with relatively smaller but still sizable conductances for $\mathrm{HCO}_{3}{ }^{-}$ $(220 \pm 17 \mathrm{pS})$ and acetate ${ }^{-}(142 \pm 7 \mathrm{pS})$. We propose a role for this channel in mediating the basolateral extrusion of acetate. Depending on the electrochemical gradients present, this channel could also serve as a pathway for the basolateral permeation of chloride and $\mathrm{HCO}_{3}{ }^{-}$.

\section{Materials and methods}

\section{Preparation of cells}

The rumen was removed immediately after slaughter of the sheep, and isolation of cells was performed according to established methods by fractional trypsinization [29, 30]. After about 1 week in culture [at $37^{\circ} \mathrm{C}$ and $5 \% \mathrm{CO}_{2}$ in Dulbecco's modified Eagle's medium supplemented with non-essential amino acids, sodium pyruvate, and 10\% fetal bovine serum (Biochrom)], cells were reseeded onto glass coverslips and cultured for another 2-4 days before being used in experiments. Only single cells with no attachments to other cells were used for patch-clamping. Left-over cells were reseeded. After a maximum of three passages, cells were discarded.

\section{Electrophysiological measurements}

All patch-clamp experiments were performed essentially as in previous studies [26, 27, 31]. Pipettes were pulled with a DMZ-Universal-Puller (Zeitz-Instruments, Munich, Germany) using borosilicate glass capillaries (Harvard Apparatus, Holliston, MA, USA). Currents between the patch pipette and an electrode placed in the perfusion chamber were recorded using an EPC 9 patch-clamp amplifier (HEKA Elektronic, Lambrecht, Germany). Pulse generation, data collection, and analysis were performed with commercially available software (TIDA for Windows,
HEKA Elektronic, Lambrecht, Germany) and filtered with a $2.9-\mathrm{kHz}$ Bessel filter. Records were corrected for capacitance via TIDA software. Positive ions flowing into the pipette correspond to a negative current and are depicted in the figures as going downward. Conversely, negative ions flowing from the bath across the cell membrane into the pipette generate a current that is depicted as going upward in the figures.

Two types of pulse protocols were applied. Conventional voltage pulse protocols were used that recorded data at a sampling rate of $5 \mathrm{kHz}$ ("pulse protocol I", Fig. 1). Voltage was increased from -120 to $100 \mathrm{mV}$ in steps of $10 \mathrm{mV}$, returning to a holding potential of $-40 \mathrm{mV}$ between each step. Alternately, current responses were recorded at $100 \mathrm{~Hz}$ by using a protocol that generated steps of 200-ms duration to voltages between -120 and $100 \mathrm{mV}$ in $20-\mathrm{mV}$ steps, returning to a holding potential of $-40 \mathrm{mV}$ for $200 \mathrm{~ms}$ between each step ("pulse protocol II", Fig. 2). This protocol was repeated continuously to allow the monitoring of current responses of the cells to changes in external solution. For single-channel experiments, data were sampled at $10 \mathrm{kHz}$ and filtered with a $250-\mathrm{Hz}$ lowpass Bessel filter after recording.

In all experiments, cells were allowed to equilibrate for at least $3 \mathrm{~min}$ after the whole-cell configuration had been achieved. During this time, voltages were clamped in alteration with the pulse protocols I and II, and the current was monitored. Cells that did not reach stable current levels during this equilibration period were discarded. If the current-voltage relationship was linear with no signs of channel activation/inactivation and a reversal potential of $0 \mathrm{mV}$ was measured, the seal was judged to be ruptured, and the measurement was discontinued.

\section{Perfusion of the bath chamber}

All perfusion solutions were warmed to $37^{\circ} \mathrm{C}$ immediately before infusion into the $200 \mu \mathrm{l}$ perfusion chamber via a perfusion cannula (PH01, multichannel systems, Reutlingen, Germany) connected to a temperature controller (TC01/2, multichannel systems, Reutlingen Germany). The solutions were applied via two separate but identical pumps (MS/CA4/840, Ismatec, Glattbrugg-Zürich, Switzerland), both of which were equipped with four parallel lanes of high-precision Tygon tubing (Ismatec) to ensure identical flow rates $\left(4 \mathrm{ml} \mathrm{min}^{-1}\right)$. All eight lanes ended in a millimanifold (ALA Scientific Instruments, Westbury, NY, USA) attached to the heating cannula (PH01) and leading into the perfusion chamber. Solution from lanes not in immediate use for cell perfusion were recirculated into the storage containers ( $50 \mathrm{ml}$ syringes, Heiland, Germany) via eight separate three-lane valves, ensuring constant mixing and constant pressure in all parts of the system at all times 
Fig. 1 Whole-cell currents of two individual ruminal epithelial cells filled with K-gluconate solution. a Original trace of cell showing outwardly rectifying conductances in $\mathrm{NaCl}$ solution. b Same cell in $\mathrm{KCl}$ solution, showing increase in inward and outward current level. c Washout of $\mathrm{KCl}$ by $\mathrm{NaCl}$ solution (same cell). d and e Original traces of another cell, showing current that is reduced by replacement of chloride with gluconate. $\mathbf{f}$ Difference current (trace $\mathbf{d}$ minus trace $\mathbf{e}$ )

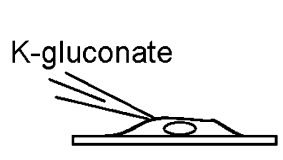

a

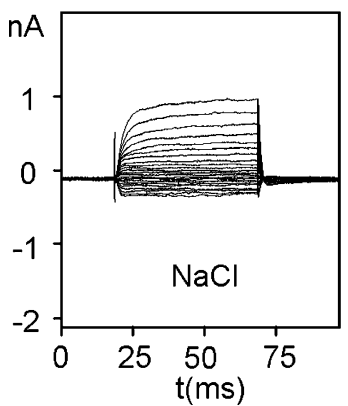

d

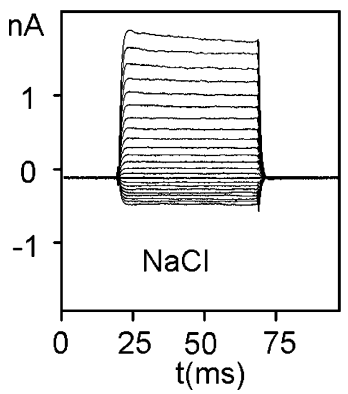

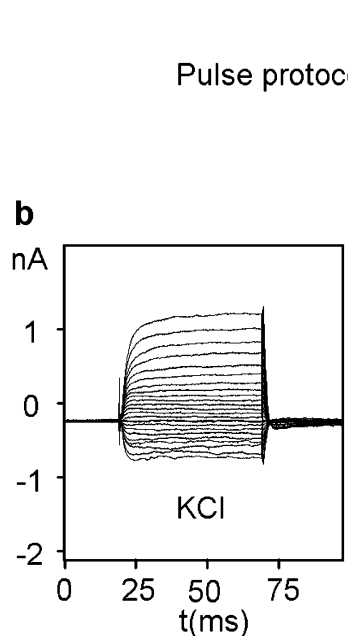

e

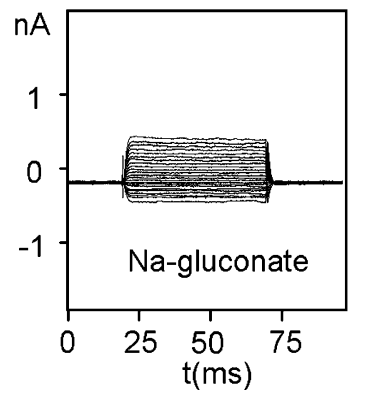

$100 \mathrm{mV}$

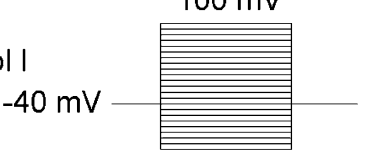

C

$-120 \mathrm{mV}$

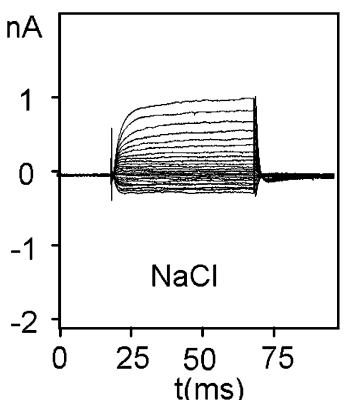

f

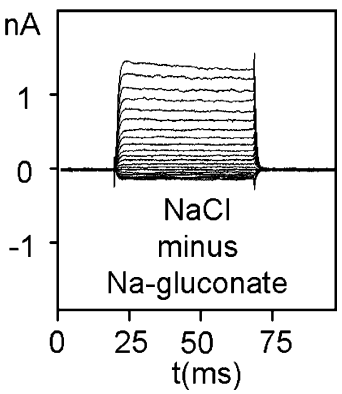

and preventing backflow of the solution being tested into other parts of the system via the manifold.

Solutions and chemicals

For whole-cell experiments, the pipette solution designated as "K-gluconate solution" contained (in millimoles per liter): $123 \mathrm{~K}$-gluconate, $10 \mathrm{NaCl}, 10 \mathrm{Hepes}, 1 \mathrm{KH}_{2} \mathrm{PO}_{4}, 0.8$ $\mathrm{CaCl}_{2}, 0.9 \mathrm{MgCl}_{2}, 5$ EGTA, adjusted to $\mathrm{pH} 7.2$ with Tris. Extracellular $\mathrm{NaCl}$ solution contained (millimoles per liter): $130 \mathrm{NaCl}, 1 \mathrm{NaH}_{2} \mathrm{PO}_{4}, 5 \mathrm{KCl}, 10$ Hepes, $1.7 \mathrm{CaCl}_{2}, 0.9$ $\mathrm{MgCl}_{2}$. The $\mathrm{NaCl}$ of this basic recipe was substituted by either $\mathrm{KCl}$, Na-gluconate, or K-gluconate to give the solutions designated by these ions and adjusted to 290 mosmol $1^{-1}$ with the dominant salt. Unless indicated otherwise, the $\mathrm{pH}$ was adjusted to 7.4 with Tris. All other experiments (i.e., whole-cell experiments with Na-gluconate pipette solution and the single-channel experiments) were performed with solutions that contained $138 \mathrm{mmol} \mathrm{l}^{-1} \mathrm{Na}^{+}$or $130 \mathrm{mmol}^{-1} \mathrm{NMDG}\left(+8 \mathrm{mmol} \mathrm{l}^{-1} \mathrm{Na}^{+}\right)$as indicated, $130 \mathrm{mmol} \mathrm{l}^{-1}$ of the anion as indicated, and $0.9 \mathrm{Mg}^{2+}, 1.7$ $\mathrm{Ca}^{2+}, 5 \mathrm{mmol} \mathrm{l}{ }^{-1} \mathrm{~K}^{+}, 1 \mathrm{mmol} \mathrm{l}{ }^{-1} \mathrm{H}_{2} \mathrm{PO}_{4}^{-}, 18.2 \mathrm{mmol}{ }^{-1}$ $\mathrm{Cl}^{-}$, and $10 \mathrm{mmol}^{-1}$ Hepes. Solutions for use on the intracellular side of the cell membrane were buffered with 5 mmol $1^{-1}$ EGTA, and the $\mathrm{pH}$ was adjusted to 7.2 with Tris. Unless indicated otherwise, solutions for use on the extracellular side of the membrane were adjusted to $\mathrm{pH} 7.4$
(Tris); subsequently, the osmolarity was raised to the (measured) level of the intracellular solution with mannitol. Solutions were frozen in small aliquots $(50$ or $100 \mathrm{ml})$ to allow rapid thawing at $37^{\circ} \mathrm{C}$ when needed. The $\mathrm{pH}$ of the experimental solutions was monitored immediately before use.

All chemicals for making these solutions were obtained from Carl Roth GmbH (Karlsruhe, Germany) or Sigma Aldrich (St. Louis, MO, USA). To ensure constant concentrations of calcium and magnesium, appropriate amounts of a commercially produced $1 \mathrm{~mol} \mathrm{l}^{-1}$ standard solution were added (Fluka, Switzerland). Commercially unavailable salts such as NMDG-gluconate or NMDG-acetate were produced by titrating $N$-methyl-D-glucamine (Fluka) with gluconic acid (Sigma Aldrich) or acetic acid (Fluka) to a pH of 7.

All blockers used in the study were obtained from Sigma Aldrich or Fluka. Solutions containing blockers were protected from light throughout. Diisothiocyanato-stilbene-2,2'disulfonic acid (DIDS) was directly and slowly added to the prewarmed stirred solutions $\left(37^{\circ} \mathrm{C}\right)$. Stock solutions of niflumic acid, flufenamic acid, or 5-nitro-2-(3-phenylpropylamino) benzoic acid were prepared by dissolving appropriate amounts of the substances in dimethyl sulphoxide (DMSO). These stock solutions were stored at $-20^{\circ} \mathrm{C}$ and added to the prewarmed test solution at a ratio of 1:1,000 to yield the concentrations indicated.

The mercurial derivative $p$-chloromercuribenzoate was difficult to dissolve, both directly in aqueous solutions and 
Fig. 2 Whole-cell currents of individual ruminal epithelial cells filled with K-gluconate solution and superfused with $\mathrm{NaCl}$ solution or as indicated by the bars. a Response of single cell showing rapid responses when bath solution was changed from $\mathrm{NaCl}$ to Na-gluconate or Na-acetate. b Different cell showing gradual induction of current in response to Na-acetate, part of which depends on the presence of chloride. c Original trace showing responses to $\mathrm{KCl}$, $\mathrm{K}$-gluconate, and $\mathrm{K}$-acetate solution. Note the increase in inward current in response to the acetate-containing solution, suggesting induction of K-currents. Note also the prolonged washout phase

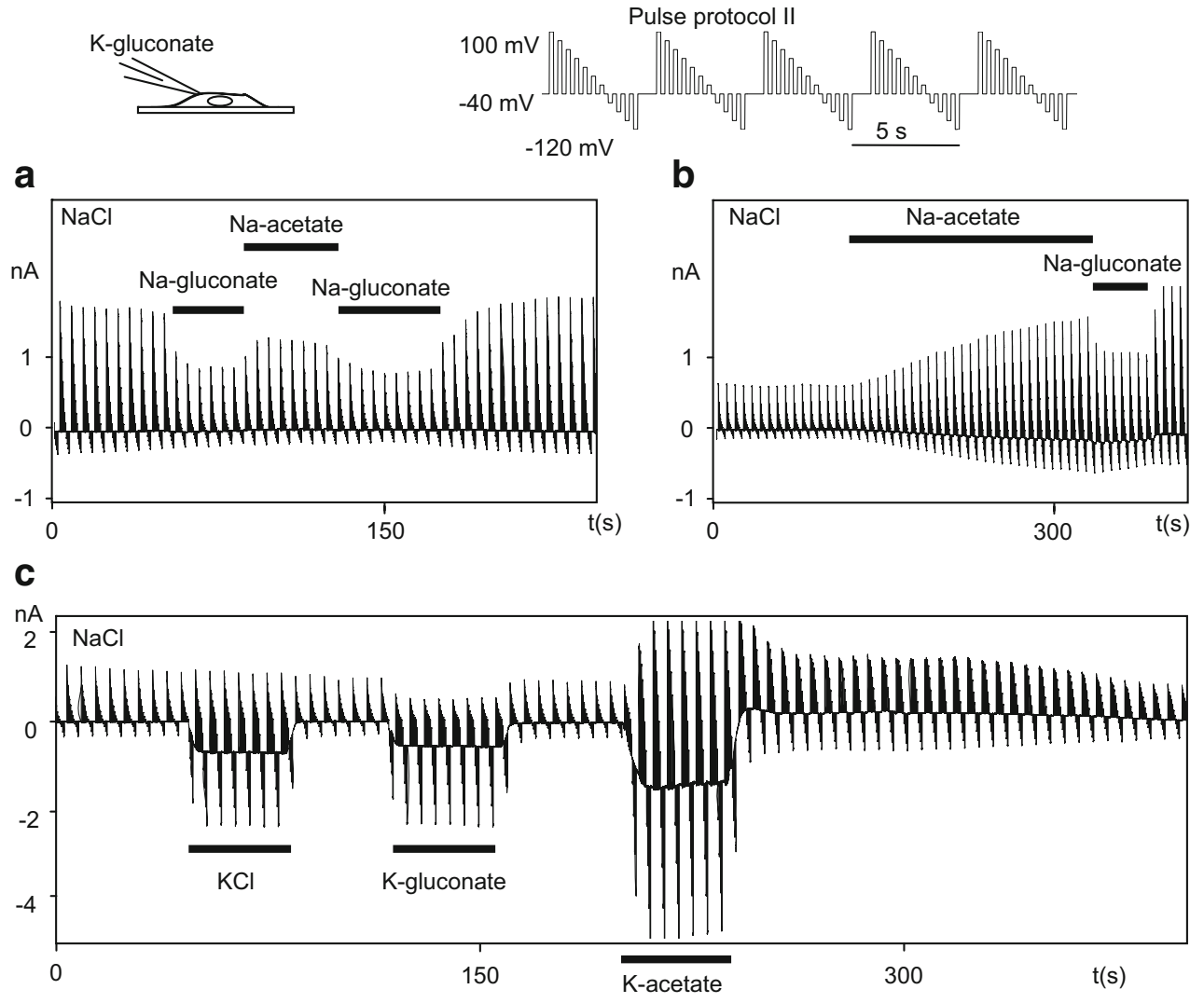

in DMSO. In $\mathrm{NaCl}$ Ringer, the direct addition of $p$ chloromercuribenzoate resulted in a milky deposit, which was removed from the solution by filtration prior to experiments. However, when the powder was slowly sprinkled into prewarmed Na-acetate solution under continuous stirring, no visible precipitate formed, and the solution was used without prior filtration.

\section{Analysis of the data}

To compare whole-cell data from the different cells with each other, currents were normalized to capacitance as measured with TIDA software. Alternately, currents were allowed to stabilize in $\mathrm{NaCl}$ solution as indicated above. The current level at $100-\mathrm{mV}$ pipette potential was then assigned a value of $100 \%$. All other currents were expressed as a percentage of this value obtained at the beginning of the experiment. Reversal potentials were estimated by linear regression between the current values at just above and just below the zero level for each cell and corrected for liquid junction potential according to established methods [32].

Data were tested by using the Kolmogorov-Smirnov test for normality (SigmaStat 3.0). All data drawn from a normally distributed collective were tested for significance by using the paired or unpaired Student's $t$ test and standard software (SigmaStat 3.0). Data that were not normally distributed were tested by using the Wilcoxon Signed Rank Test (Sigmastat 3.0). Statistical comparison between multiple groups was made by using one-way repeated measures ANOVA and the Holm-Sidak method for multiple pairwise comparisons (SigmaStat 3.0). Curves were fitted with SigmaPlot 8.0.

\section{Evaluation of single-channel data}

Assuming independence, single-channel conductances were fitted by using the current-voltage formulation of the Goldman-Hodgkin-Katz equation for three anions (chloride, acetate, and gluconate) [33]:

$$
I=E \cdot F^{2} /(R \cdot T)\left(P_{\mathrm{Cl}}[\mathrm{Cl}]_{\mathrm{o}}+P_{\mathrm{Gl}}[\mathrm{Gl}]_{\mathrm{o}}+P_{\mathrm{Ac}}[\mathrm{Ac}]_{\mathrm{o}}-\left(P_{\mathrm{Cl}}[\mathrm{Cl}]_{\mathrm{i}}+P_{\mathrm{Gl}}[\mathrm{Gl}]_{\mathrm{i}}+P_{\mathrm{Ac}}[\mathrm{Ac}]_{\mathrm{i}}\right) * \exp (-E \cdot F /(R \cdot T))\right) /(1-\exp (-E \cdot F /(R \cdot T)))
$$


In this equation, $E$ designates the potential (calculated from the pipette potential by correcting for liquid junction potential [32]), $R$ the gas constant, $T$ the temperature, and $F$ the Faraday constant. $P_{x}$ designates the permeability for substance $X ;[X]_{\mathrm{i}}$ and $[X]_{\mathrm{o}}$ are the concentrations of the substance $X$ inside and outside of the pipette. In symmetrical chloride solution with just one anion $\left([\mathrm{Cl}]_{\mathrm{i}}=[\mathrm{Cl}]_{\mathrm{o}}\right.$, $[\mathrm{Gl}]_{\mathrm{i}}=[\mathrm{Gl}]_{\mathrm{o}}=0$ ), this equation can be simplified to:

$I=E \cdot F^{2} /(R \cdot T) \cdot P_{\mathrm{Cl}}[\mathrm{Cl}]$.

Using Eq. 2, the values for $P$ resulting from the fit of currents in asymmetrical solutions were used to predict the conductance $C$ in symmetrical $130 \mathrm{mmol}^{-1}$ solution at a given concentration of the anion $([\mathrm{Cl}])$, provided that the interaction of different anions in the pore was marginal:

$C_{\mathrm{Cl}}=I / E=F^{2} /(R \cdot T) \cdot P_{\mathrm{Cl}} \cdot[\mathrm{Cl}]$.

Gating model

A modification of classical gating theory was developed in order to explain the voltage dependence of open proba- bility. In the model, a charged particle with gating charge $n$ lies within the channel pore. At $0 \mathrm{mV}$, the channel is open. When a negative voltage is applied, the charged gating particle moves along the field until it obstructs one end of the pore and the channel is closed, thus changing from state $P_{o}$ to $P 1_{c}$. When a positive voltage is applied, the gate will move in the opposite direction until it obstructs the pore at the other end, and the channel is in a second closed state $\mathrm{P} 2_{\mathrm{c}}$. If the charge moves along a fraction $\alpha$ of the total length of the pore in order to move from state $\mathrm{P}_{\mathrm{o}}$ to $\mathrm{P} 1_{c}$, the energy difference between these two states will be given by a voltage-independent term $w$ and a voltage-dependent term $\alpha \cdot n \cdot E \cdot q_{\mathrm{e}} / k_{\mathrm{b}} \cdot T$, where $E$ is the potential across the entire membrane, $q_{\mathrm{e}}$ is the elementary charge, $k_{\mathrm{b}}$ is the Boltzmann constant, and $T$ is the temperature [33]. According to Boltzmann theory, the relative probability of finding the particle in states $\mathrm{P}_{\mathrm{o}}$ and $\mathrm{P} 1_{\mathrm{c}}$ is given by $\mathrm{P}_{\mathrm{o}} / \mathrm{P} 1_{\mathrm{c}}=\exp \left(w-\alpha \cdot n \cdot E \cdot q_{\mathrm{e}} /\left(k_{\mathrm{b}} \cdot T\right)\right)$. By analogy, $\quad \mathrm{P}_{\mathrm{o}} / \mathrm{P} 2_{\mathrm{c}}=\exp \left(v+\beta \cdot n \cdot E \cdot q_{\mathrm{e}} /\left(k_{\mathrm{b}} \cdot T\right)\right)$ (where $v$ is voltage independent, and $\beta$ designates the fractional distance between $\mathrm{P}_{\mathrm{o}}$ to $\mathrm{P} 2_{\mathrm{c}}$ ). The probability that the channel is open will thus be given by

$\mathrm{P}_{\mathrm{o}} /\left(\mathrm{P} 1_{\mathrm{c}}+\mathrm{P}_{\mathrm{o}}+\mathrm{P} 2_{\mathrm{c}}\right)=1 /\left[\exp \left(-\left(w-\alpha \cdot n \cdot E \cdot q_{\mathrm{e}} /\left(k_{\mathrm{b}} \cdot T\right)\right)\right)+1+\exp \left(-\left(v+\beta \cdot n \cdot E \cdot q_{\mathrm{e}} /\left(k_{\mathrm{b}} \cdot T\right)\right)\right)\right]$.

\section{Results}

Whole-cell experiments on cells filled with K-gluconate:

\section{Replacement of external sodium by potassium}

In a first series of experiments, cells were filled with the K-gluconate pipette solution (see "Materials and methods") and superfused with $\mathrm{NaCl}$ bath solution, thereby resembling physiological conditions. When the pipette potential was clamped to $-120 \mathrm{mV}$, the cells had a mean inward current of $-7.6 \pm 0.8 \mathrm{pA} / \mathrm{pF} \quad(n=49)$. At a pipette potential of $100 \mathrm{mV}$, a current of $18 \pm 2 \mathrm{pA} / \mathrm{pF} \quad(n=49)$ could be measured. The reversal potential (corrected for liquid junction potential) was $-30 \pm 2 \mathrm{mV}(n=49)$. Replacement of external $\mathrm{Na}^{+}$with $\mathrm{K}^{+}$resulted in an increase in inward current at $-120 \mathrm{mV}$ to $-22 \pm 4 \mathrm{pA} / \mathrm{pF} \quad(n=23, p<0.001$, extracellular $\mathrm{NaCl}$ versus extracellular $\mathrm{KCl}$ ), confirming previous data suggesting that ruminal epithelial cells express a potassium conductance [26] (for a representative original recording from one cell, see Fig. 1a, b, c). Relative to the level in $\mathrm{NaCl}$ solution (100\%), the outward current at $100 \mathrm{mV}$ increased to $130 \pm 13 \%(n=23, p<0.01)$, suggesting an increase in potassium conductance by exposure to potassium [26]. Elevation of the external potassium concentration changed the reversal potential to $-10.9 \pm$ $2.6 \mathrm{mV}(n=23, p<0.001)$. The negative reversal potential suggested a contribution of chloride to total reversal potential.

\section{Replacement of external chloride by gluconate}

In agreement with this, replacement of $130 \mathrm{mmol}^{-1}$ of $\mathrm{NaCl}$ by an equimolar concentration of Na-gluconate resulted in a depolarization of the reversal potential to $-19 \pm 5 \mathrm{mV}(p<0.01, n=23$; for an original recording of one cell, see Fig. 1d, e, f). Following exposure to external Kgluconate solution, cells depolarized completely (to $0.9 \pm$ $0.7 \mathrm{mV}, n=23, p<0.001$ versus $\mathrm{NaCl}$ ).

\section{Replacement of external gluconate by acetate}

In order to test the permeability of the cells for acetate, Nagluconate was replaced by $130 \mathrm{mmol} \mathrm{l}^{-1} \mathrm{Na}$-acetate in the 
external solution, resulting in a strong hyperpolarization of the cells to $-36 \pm 6 \mathrm{mV}(p<0.01, n=18$, Na-gluconate versus Na-acetate; for an original trace, see Fig. 2a). This hyperpolarization may reflect either an influx of the acetate anion or an increase in the efflux of potassium from the K-gluconate-filled interior.

In addition to the hyperpolarization observed, acetateinduced variable increases in the current not just at a positive pipette potential (reflecting either an influx of acetate or an efflux of potassium) but also at negative potential levels (reflecting an influx of sodium or an efflux of gluconate; Fig. 2b). To simplify the interpretation of the results, additional experiments were conducted with solutions in which external $\mathrm{Na}^{+}$was replaced by external $\mathrm{K}^{+}$(Fig. 2c). In this situation and given the low permeability of the membrane for gluconate [26, 34], the current at $-120 \mathrm{mV}$ should represent the influx of potassium.

Experiments showed that the inward current in $\mathrm{K}$-acetate solution was significantly higher than in $\mathrm{KCl}$ solution $(-42 \pm$ $13 \mathrm{pA} / \mathrm{pF}, n=19$ versus $-22 \pm 5 \mathrm{pA} / \mathrm{pF}, n=16, p$ (unpaired) $<$ $0.001)$ or in K-gluconate solution $(-23 \pm 7 \mathrm{pA} / \mathrm{pF}, p=0.001$ versus $\mathrm{K}$-acetate; Fig. 2c). The reversal potential in $\mathrm{K}$-acetate solution $(-1.3 \pm 1 \mathrm{mV})$ was comparable with that in $\mathrm{K}$ gluconate solution $(1 \pm 0.8 \mathrm{mV}, p=0.6)$. These data suggest that the acetate stimulated the potassium conductance of the cells. Any difference in the conductance for acetate versus gluconate was masked by the high potassium conductance of the cell.

Whole-cell experiments on cells filled with Na-gluconate solution

\section{Replacement of external chloride by gluconate}

To eliminate the potassium conductance, cells were filled with the Na-gluconate pipette solution (as described in the "Materials and methods" section). In the $\mathrm{NaCl}$ bath solution, the reversal potential and currents at positive and negative potential were not significantly different from cells filled with K-gluconate solution. This is in agreement with previous results that suggest that the potassium conductance of ruminal epithelial cells is low in $\mathrm{NaCl}$ solution and only rises with exposure to extracellular potassium [26]. In cells filled with Na-gluconate, replacement of chloride with gluconate depolarized the reversal potential from $-32 \pm 1$ to $2.9 \pm 1 \mathrm{mV}(n=40, p<0.001)$, with a return to $-30 \pm 1 \mathrm{mV}$ upon the re-addition of $\mathrm{NaCl}$ solution (Fig. 6b). Current at $100 \mathrm{mV}$ dropped from $55 \pm 7(\mathrm{NaCl})$ to $21 \pm 6 \mathrm{pA} / \mathrm{pF}(\mathrm{Na}-$ gluconate; $n=40, p<0.001$ ), returning to $59 \pm 9 \mathrm{pA} / \mathrm{pF}$ upon the re-addition of chloride (Fig. $3 \mathrm{a}, \mathrm{b}$, e, and f). In relative terms, this represents a drop from $100 \%(\mathrm{NaCl})$ to $36 \pm 9 \%$ (Na-gluconate; Fig. 6a). The permeability ratio of gluconate to chloride as calculated from the ratio of the reversal potentials
Fig. 3 Whole-cell currents of individual ruminal epithelial cells filled with Na-gluconate solution and superfused with $\mathrm{NaCl}$ solution or as indicated by the bars. a, b, c The same cell exposed to $\mathrm{NaCl}$, Na-gluconate, and $\mathrm{NaHCO}_{3}$ solutions, respectively. d Same cell as $\mathbf{a}, \mathbf{b}$, and $\mathbf{c}$ but exposed to DIDS (1 $\mathrm{mmol}$ $\left.1^{-1}\right)$ in $\mathrm{NaCl}$ solution. The current level returned to the original level after washout (data not shown). e Original trace of another cell showing the concentration-dependent block of outward current by DIDS. f In this particular cell, application of $\mathrm{NaHCO}_{3}$ induced a reversible stimulation of inward current
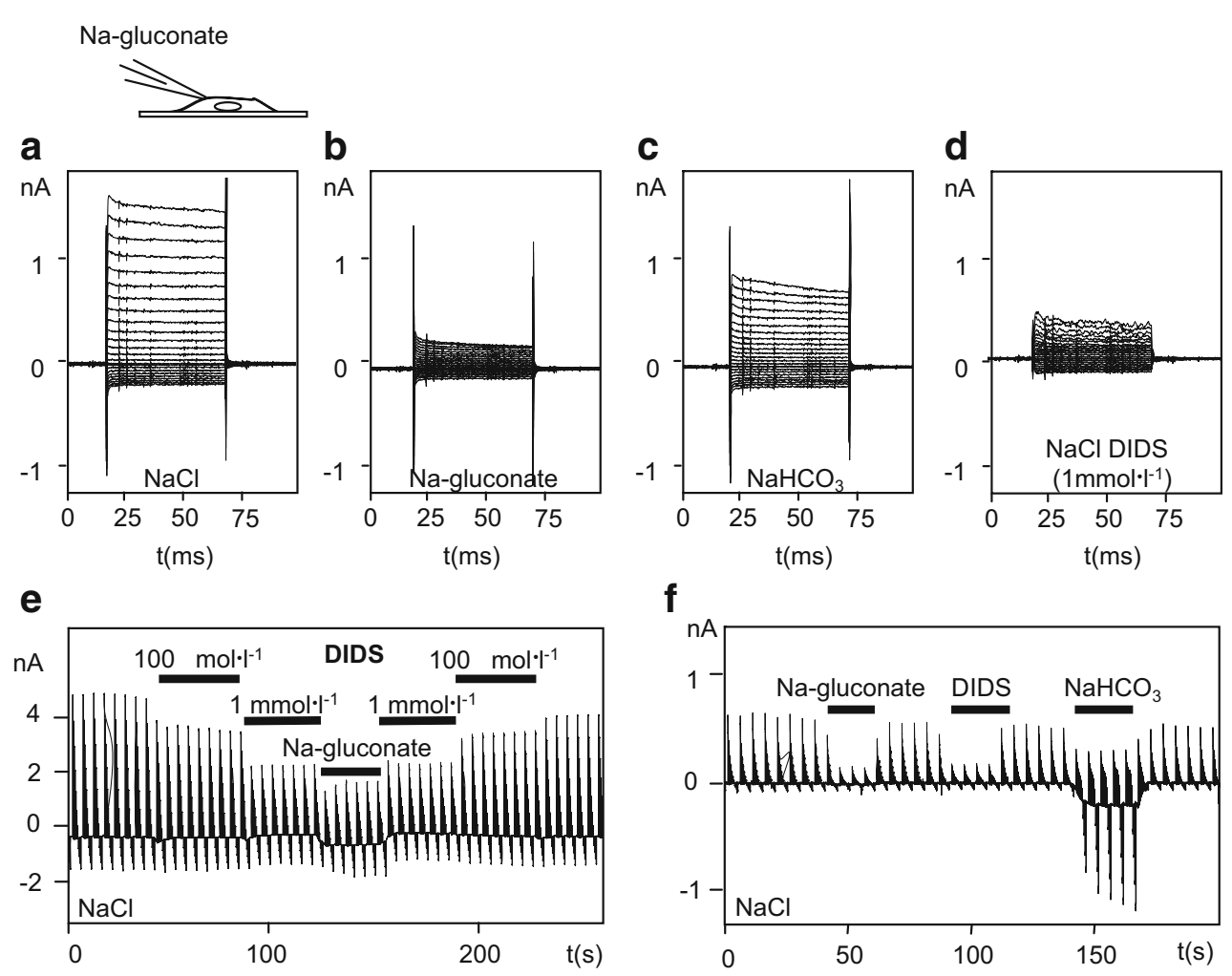

f

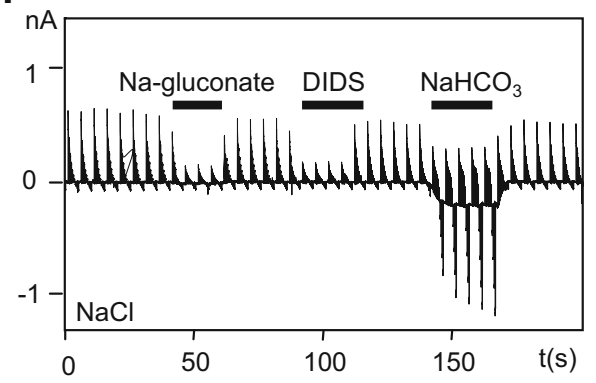


(see "Materials and methods") was $p\left(\mathrm{glu}^{\top}\right) / p\left(\mathrm{Cl}^{-}\right)=0.29 \pm 0.02$ $(n=40)$. Conversely, the effects of replacing chloride with gluconate on the current at a pipette potential of $-120 \mathrm{mV}$ were not significant $(n=40)$.

\section{Replacement of external chloride by bicarbonate}

At $100 \mathrm{mV}$, the replacement of external $\mathrm{NaCl}$ by $\mathrm{NaHCO}_{3}$ ( $\mathrm{pH} 7.4$ ) reduced the current to $61 \pm 7 \%$ of the current level in $\mathrm{NaCl}$ solution ( $n=7, p<0.01$; Figs. $3 \mathrm{c}$ and e and Fig. 6). The reversal potential of cells bathed in $\mathrm{NaHCO}_{3}$ solution was $-21 \pm 2 \mathrm{mV}(n=7)$. This value lies between that observed in $\mathrm{NaCl}$ solution $(p<0.01)$ and that in $\mathrm{Na}$ gluconate solution $(p<0.01)$, suggesting that the conductance for $\mathrm{HCO}_{3}{ }^{-}$lies between the conductance for $\mathrm{Cl}^{-}$and gluconate ${ }^{-}$. An enhancing effect of $\mathrm{HCO}_{3}{ }^{-}$on the inward current (at $-120 \mathrm{mV}$ ) could sometimes be observed in individual cells (Fig. 3f). However, with regard to all cells tested, changes in the inward current level did not pass tests for significance. The permeability ratio of $\mathrm{HCO}_{3}^{-}$to $\mathrm{Cl}^{-}$ was $p\left(\mathrm{HCO}_{3}{ }^{-}\right) / p\left(\mathrm{Cl}^{-}\right)=0.73 \pm 0.05(n=7)$.

\section{Replacement of external chloride by nitrate}

To test the conductance of the channel for nitrate, $130 \mathrm{mmol}^{-1}$ $\mathrm{NaCl}$ were replaced by an equimolar amount of $\mathrm{NaNO}_{3}$ in the external solution. The reversal potential $(-34 \pm 4 \mathrm{mV}, n=$
10, $p=0.3$ ) and currents at positive and negative pipette potentials were not significantly influenced by this maneuver (Figs. 4f and 6). These results suggested that the conductances for chloride and nitrate were similar. To test for any blocking effects of nitrate on chloride conductance, $10 \mathrm{mmol}$ $1^{-1}$ nitrate was used to replace $10 \mathrm{mmol} \mathrm{l}^{-1}$ chloride; again, no significant effects were seen $(n=4)$.

\section{Replacement of external chloride or gluconate by acetate}

The replacement of external $\mathrm{NaCl}$ solution by $\mathrm{Na}$-acetate solution depolarized the cells to $-15 \pm 1 \mathrm{mV}(n=29, p<$ 0.001 ), suggesting that the conductance of the cells for acetate was considerably smaller than that for chloride. Conversely, when cells were first superfused with $\mathrm{Na}-$ gluconate solution and subsequently by $\mathrm{Na}$-acetate, cells were reversibly hyperpolarized $(n=28, p<0.001)$, suggesting that the conductance of the cells for acetate was greater than the conductance for gluconate (Figs. 4, 5, and 6). Of note, sodium was in equilibrium across the cell membrane in these experiments so that induction of sodium currents could not have contributed to the lowering of the reversal potential by superfusion with acetate. The permeability ratio of acetate to chloride was $p\left(\right.$ acetate $\left.^{-}\right) / p\left(\mathrm{Cl}^{-}\right)=0.53 \pm$ $0.03(n=28)$. This value was significantly higher than the permeability $p\left(\mathrm{glu}^{-}\right) / p\left(\mathrm{Cl}^{-}\right)$of $0.28 \pm 0.03(n=28)$ seen in this group of acetate-treated cells $(p<0.001)$.
Fig. 4 Whole-cell recordings from one ruminal epithelial cell filled with Na-gluconate solution and consecutively superfused with different bath solutions in the order of a to h. a, b, c Currents in $\mathrm{NaCl}$ Na-gluconate, and Na-acetate solution, respectively. d Effect of DIDS $\left(1 \mathrm{mmol} \mathrm{l}^{-1}\right)$ on currents in Na-acetate solution. e Currents after washout of DIDS. f $\mathrm{NaNO}_{3}$ solution. $\mathbf{g}$ $\mathrm{NaCl}$ solution. Note the increase in outward current amplitude relative to trace in $\mathbf{a}$. $\mathbf{h}$ Application of Na-acetate solution adjusted to a $\mathrm{pH}$ of 6.4 , showing the stimulation of an inward current. Cell capacitance (in picofarad) was measured immediately before each recording and is indicated in the figures
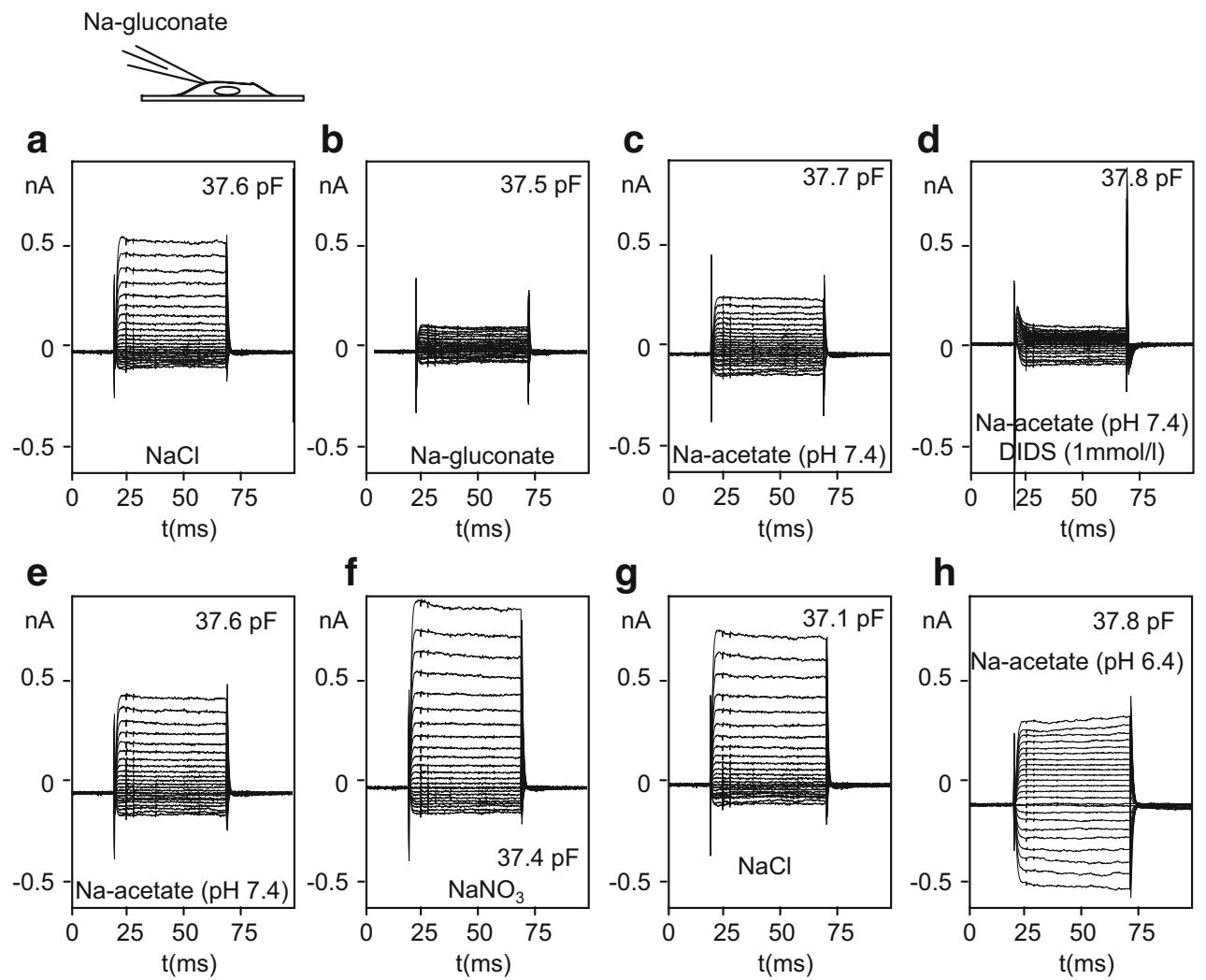

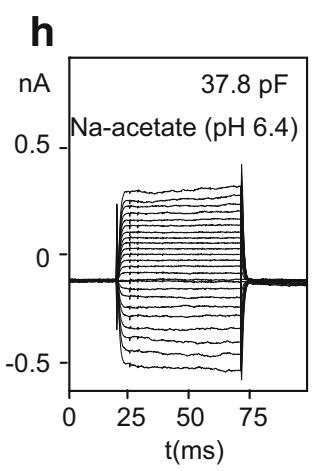


Fig. 5 Whole-cell currents of individual ruminal epithelial cells filled with Na-gluconate solution and exposed to Na-acetate solution. a At $100 \mathrm{mV}$, current level was highest in $\mathrm{NaCl}$ solution, lowest in Na-gluconate solution, and medium in Na-acetate solution. The trace shows a cell with stable conductance levels and in which the effects of acetate did not depend on external $\mathrm{pH}$. b Cell showing very pronounced induction of current following exposure to acetate. The induced current could be blocked by DIDS $\left(1 \mathrm{mmol}^{-1}\right)$. Current level eventually returned to initial values after a return to $\mathrm{NaCl}$ solution. c Trace showing the induction of a DIDS-sensitive current by exposure to acetate. The current was also sensitive to $p$-chloromercuribenzoate $\left(1 \mathrm{mmol} \mathrm{l}{ }^{-1}\right)$ and to removal of chloride. (Unless indicated otherwise, the cells were superfused with $\mathrm{NaCl}$ solution)
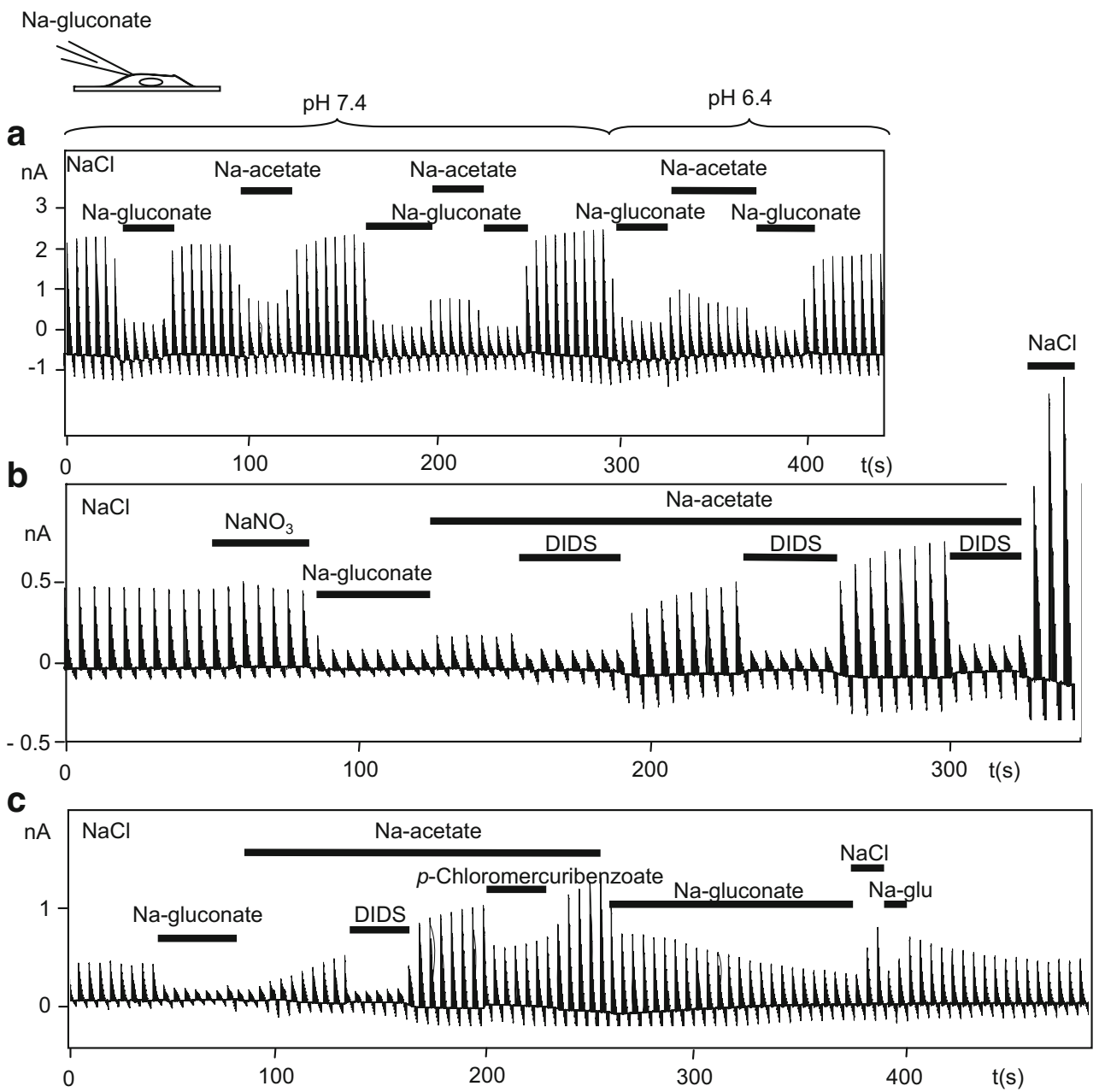

Figure 4 shows the current responses from a typical cell. Current at $100 \mathrm{mV}$ dropped when chloride was replaced by gluconate (Fig. 4b) and rose when gluconate was replaced by acetate (Fig. 4c). The current could be blocked by DIDS (Fig. 4d). Current level tended to rise with continued exposure to acetate (Fig. 4e), suggesting an increase in the conductance of the cell for anions and/or cations (Fig. $4 \mathrm{f}$ and $\mathrm{g})$.

However, inspection of individual currents showed extensive variability. Figure 5a shows the trace of a cell exhibiting no sign of an induction of conductance by acetate. Current levels responded promptly and without a notable time delay to the changes in the composition of the applied bath solution. Conversely, Fig. 5b and c show traces of cells displaying an extremely pronounced increase in current amplitude over the time of exposure to acetatecontaining solution.

These acetate-induced currents were partially sensitive to DIDS, to the removal of chloride, and to application of $p$ chloromercuribenzoate (Fig. 5b and c) and decayed slowly with time after a return to the original $\mathrm{NaCl}$ solution (Fig. 5c). These results suggest that, following exposure to acetate, both the efflux of $\mathrm{Na}$ from the cell and the influx of chloride and sodium from the bath into the cell are higher than at the beginning of the experiment. Because of the great variability, changes in currents did not pass tests for significance (Fig. 6a).

\section{Effect of acetate on cell capacitance}

To check for the possibility that swelling of the cells occurred during acetate exposure, cell capacitance was measured after each change in solution. Although small increases in capacitance could be observed in individual cells (compare Fig. 4), in other cells, acetate decreased capacitance. Statistically, the mean capacitance in $\mathrm{NaCl}$ solution at the beginning of the experiment was $39 \pm 4 \mathrm{pF}$ $(n=14)$ and did not change significantly following exposure to acetate. It appears possible that the patch pipettes [access resistance: $13.6 \pm 0.8 \mathrm{M} \Omega(n=14)]$ were wide enough to allow reflux into the pipettes, thus preventing cell swelling in the majority of the cells. However, no correlation was seen between access resistance, cell capacitance, and the change in capacitance following exposure to acetate. 
Fig. 6 Summary of the results. Cells were filled with Na-gluconate solution and superfused with various bath solution, as indicated. a Whole-cell currents at $+100 \mathrm{mV}$ (positive values) and $-120 \mathrm{mV}$ (negative values) in percent of the initial current at $+100 \mathrm{mV}$ in $\mathrm{NaCl}$ solution.

b Reversal potentials. Unless indicated otherwise, DIDS was given at a concentration of $1 \mathrm{mmol}^{-1}$. The small numbers over the bars designate the number of experiments. Testing for significant differences versus $\mathrm{NaCl}$ solution was performed for all experiments with $n>3$. Brackets indicate additional comparisons. ${ }^{\mathrm{ns}} p>0.05$, ${ }^{*} p<0.05,{ }^{* *} p<0.01$ $* * * p<0.001$ (Holm-Sidak)

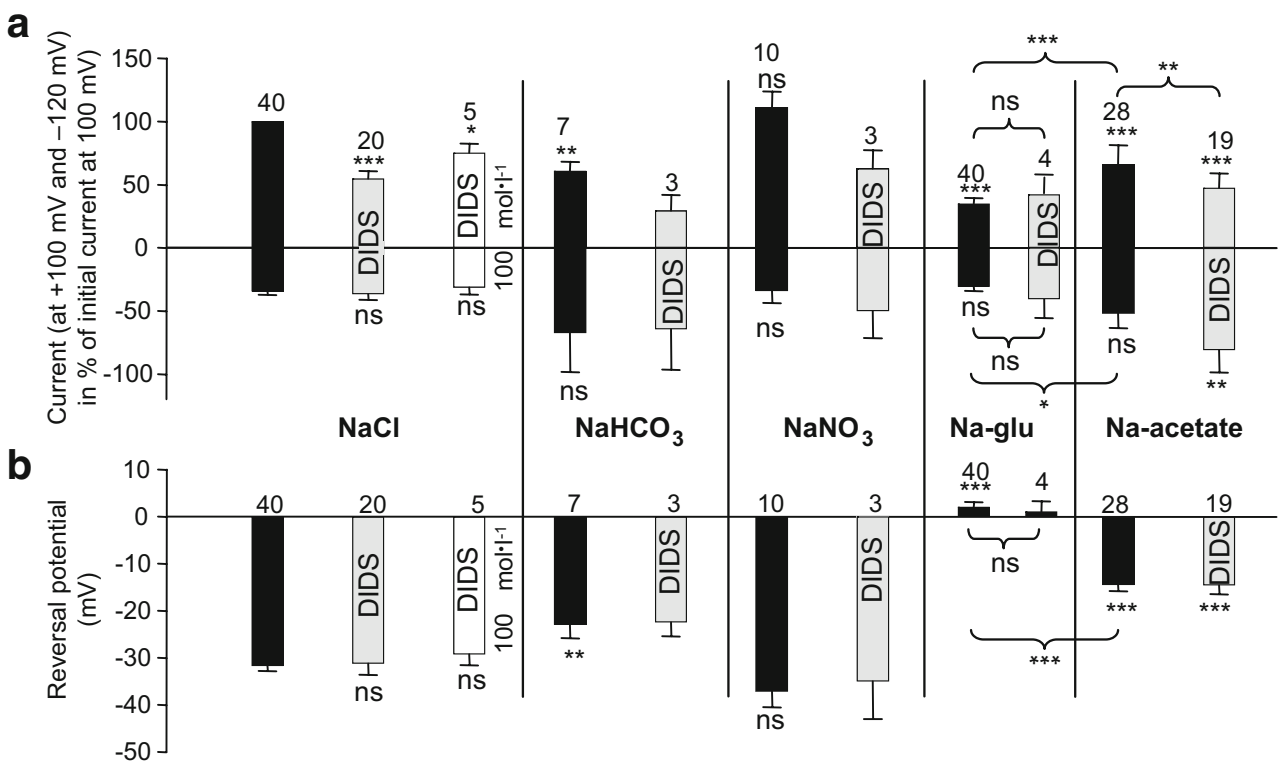

Likewise, no clear correlation between the induction of current, cell capacitance, and access resistance could be demonstrated. In light of the finding that a change in the osmolarity of the bath solution can also lead to the induction of currents in ruminal epithelial cells or to cell rupture (data not shown), acetate-induced currents may be caused by moderate swelling of the cells. Alternately, they may serve to prevent such swelling in native cells. Further evidence is necessary to clarify the situation.

\section{Effect of pH on acetate-induced currents}

In an attempt to investigate whether the acetate-induced currents were related to cell swelling and/or changes in cytosolic $\mathrm{pH}$, the $\mathrm{pH}$ of the superfusing solution was changed to 6.4 in some experiments. This should increase the percentage of acetate in the undissociated lipophilic form and thus increase the influx of acetate into the cells. As in a previous study [26], no effect could be seen when the $\mathrm{pH}$ of a Na-gluconate bath solution was switched from 7.4 to 6.4 ( $n=3$; Fig. 5a). In seven cells, the same maneuver was performed in Na-acetate solution. The inward current at a negative pipette potential could be seen to rise transiently in a number of cells (Fig. 4h), suggesting an increase in the influx of sodium into the cells. However, other cells did not respond in this manner (Fig. 5a). Overall, the currents in solutions with a $\mathrm{pH}$ of 6.4 did not differ significantly from those at a $\mathrm{pH}$ of 7.4. However, the great variability of the responses may have prevented detection of statistically significant differences. The possibility that these currents were induced by changes in cytosolic $\mathrm{pH}$ cannot and should not be ruled out.

\section{Effect of anion channel blockers}

Application of DIDS on Na-gluconate filled cells in $\mathrm{NaCl}$ bath solution reduced current at $100 \mathrm{mV}$ in a dosedependent manner. Relative to the original level in the absence of DIDS (100\%), current at $100 \mathrm{mV}$ fell to $75 \pm 7 \%$ (at $100 \mu \mathrm{mol} 1^{-1}$ DIDS; $n=5, p<0.05$ ) and $54 \pm 6 \%$ (at $1 \mathrm{mmol}^{-1}$ DIDS; $p<0.001, n=20$ ), respectively. The current at $-120 \mathrm{mV}$ and reversal potential were not affected by DIDS at either concentration (Figs. 3 to 6).

In Na-acetate solution, the current at $100 \mathrm{mV}$ was also blocked by DIDS ( $1 \mathrm{mmol} \mathrm{l}^{-1}$ ), decreasing from $66 \pm 15 \%$ in Na-acetate solution without the blocker ( $\mathrm{NaCl}: 100 \%)$ to $47 \pm$ $11 \%(n=19, p<0.01$; Figs. 4d, 5b and c, 6a). Again, DIDS had no impact on the reversal potential or inward current. In three cells tested, DIDS ( $1 \mathrm{mmol} \mathrm{l^{-1 }}$ ) blocked currents generated by $\mathrm{NO}_{3}{ }^{-}$from $111 \pm 13 \%$ to $62 \pm 15 \%$. In Na$\mathrm{HCO}_{3}$ solution, current at $100 \mathrm{mV}$ was blocked from $61 \pm 7 \%$ to $29 \pm 12 \%$ by DIDS $\left(1 \mathrm{mmol} \mathrm{l}^{-1} ; n=3\right)$. Conversely, effects of DIDS $\left(1 \mathrm{mmol} \mathrm{l}^{-1}\right)$ were very small when the cells were superfused with a solution in which $130 \mathrm{mmol} \mathrm{l}^{-1}$ of chloride were replaced by gluconate ( $n=4$; Fig. 6$)$.

In $\mathrm{NaCl}$ solution and with Na-gluconate in the pipette, niflumic acid $\left(100 \mu \mathrm{mol}{ }^{-1}\right)$ led to a visible and reversible block of current at $100 \mathrm{mV}$ to $66 \pm 13 \%(n=4, p=0.07)$. The inward current and reversal potential were not affected. 5-Nitro-2-(3-phenylpropyl-amino) benzoic acid (50 $\left.\mu \mathrm{mol} \mathrm{l}^{-1}\right)$ blocked the current at $100 \mathrm{mV}$ to $76 \pm 5 \%$ of the original level $(n=4 ; p=0.05)$. Furosemide $\left(100 \mu \mathrm{mol} \mathrm{l}^{-1}\right)$, which has been shown to block a number of chloride channels, had no effect $(n=3)$. Flufenamic acid had no effect at $2 \times$ $10^{-5} \mu \mathrm{mol} \mathrm{l}^{-1}(n=5)$. 
Interestingly, $p$-chloromercuribenzoate $\left(1 \mathrm{mmol} \mathrm{l}^{-1}\right)$, which has been used to block the transport of SCFA via MCT1 across the ruminal epithelium [21], reduced the current at $100 \mathrm{mV}$ in $\mathrm{NaCl}$ solution by $15 \pm 3 \%(n=4, p<$ $0.05)$. In Na-acetate solution, a clearly visible reduction of current at $100 \mathrm{mV}$ by $29 \pm 3 \%$ could be observed $(n=7, p=$ 0.01 ; Fig. 5c). Effects on reversal potential were not significant.

Whole-cell experiments on cells filled with NMDG-gluconate solution

\section{Effect of p-chloromercuribenzoate and DIDS on the conductance for acetate}

While the reversal potentials in the previous series of experiments clearly show that acetate is conducted by ruminal epithelial cells, there is considerable evidence to suggest that at least part of the current at $100 \mathrm{mV}$ in $\mathrm{Na}$ acetate solution reflects efflux of $\mathrm{Na}^{+}$and not influx of acetate. For this reason, it cannot be ruled out that the blocking effects of DIDS and $p$-chloromercuribenzoate on the membrane currents at positive voltages reflect a decrease in the efflux of sodium from the cells. To allow a differentiation of the effects of the blockers on sodium and acetate currents, the cells were filled with an NMDGgluconate solution and superfused with $\mathrm{Na}$-acetate solution. In this situation, current at negative voltages should reflect influx of sodium into the cells, while current at positive voltages reflects influx of acetate into the cells.

In $\mathrm{NaCl}$ solution, currents of cells filled with NMDGgluconate solution were outwardly rectifying, with current at $-120 \mathrm{mV}$ only $-34 \pm 3 \%$ of the current at $100 \mathrm{mV}$. Reversal potential was $-16 \pm 2 \mathrm{mV}(n=13)$. Replacement of chloride by gluconate resulted in a strong depolarization to $15 \pm 3 \mathrm{mV}(n=8, p<0.001$ versus $\mathrm{NaCl}$ solution, HolmSidak; Fig. 7). Current at $100 \mathrm{mV}$ was only $28 \pm 3 \%$ of that in $\mathrm{NaCl}$ solution $(p<0.001)$, while inward current at $-120 \mathrm{mV}$ remained stable $(-32 \pm 6 \%$ of the initial outward current in $\mathrm{NaCl}$ solution.) Exposure to $\mathrm{Na}$-acetate induced a significant drop in reversal potential (to $-2.4 \pm 3 \mathrm{mV}, p<$ $0.001, n=8)$ and an increase of current at $100 \mathrm{mV}$ to $49 \pm$ $4 \%(p=0.003)$, while inward current remained remarkably stable $(-29 \pm 4 \%)$. Application of $p$-chloromercuribenzoate $\left(1 \mathrm{mmol}^{-1}\right)$ blocked the current at $100 \mathrm{mV}$ to $30 \pm 4 \%$ ( $n=$ $8, p=0.01$ ), with a significant shift in reversal potential to a mean value of $3.6 \pm 3 \mathrm{mV}$. This corresponds to a mean depolarization of $6.6 \pm 2 \mathrm{mV}(p=0.01$ versus Na-acetate without the blocker). Current at $-120 \mathrm{mV}$ remained stable $(-28 \pm 8 \%)$. Following re-exposure to Na-acetate solution,
Fig. 7 Whole-cell currents of cells filled with NMDGgluconate solution.

a Original recording of a trace showing the blocking effects of $p$-chloromercuribenzoate $\left(1 \mathrm{mmol}^{-1}\right)$ on the current in Na-acetate solution. b Trace of a cell showing the blocking effects of $p$-chloromercuribenzoate $\left(1 \mathrm{mmol}{ }^{-1}\right)$ and DIDS $\left(1 \mathrm{mmol} \mathrm{l}^{-1}\right)$, followed by a rupture of the seal. c Reversal potentials of cells filled with NMDG-gluconate solution. Testing for significant differences was performed versus Naacetate solution or as suggested by the brackets. ${ }^{\mathrm{ns}} p>0.05,{ }^{*} p<$ $0.05, * * p<0.01, * * * p<0.001$ (Holm-Sidak)

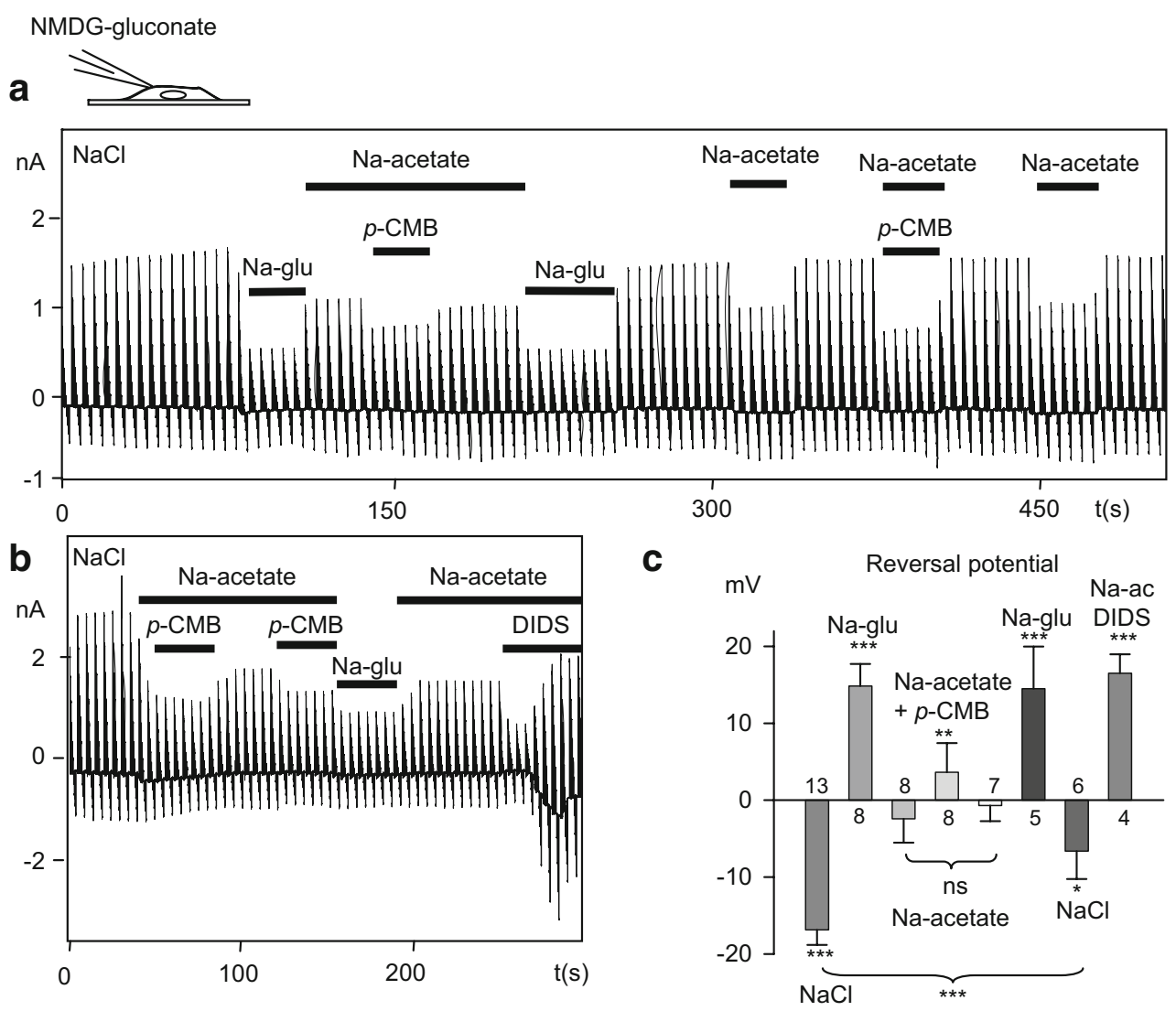


immediate washout could be observed (reversal potential: $-0.7 \pm 2 \mathrm{mV}$, current at $100 \mathrm{mV}: 42 \pm 5 \%, n=7)$. When cells were returned to $\mathrm{NaCl}$ solution, outward current rose to $68 \pm 13 \%(n=6)$, a level significantly higher than that in Naacetate solution $(p<0.001)$. These experiments clearly show that $p$-chloromercuribenzoate blocks the anion conductance of ruminal epithelial cells in a manner that is at least partially reversible. Interaction with the Na-conductance does not occur.

A subsequent exposure of the cells to DIDS $\left(1 \mathrm{mmol} \mathrm{l}^{-1}\right)$ resulted in an immediate decrease in current at $100 \mathrm{mV}$ to $30 \pm 12 \%$ ( $n=4$; Fig. 7 b). Reversal potential rose dramatically, reaching a mean peak at $16 \pm 3 \mathrm{mV}$. After this, in all four cells treated, reversal potential dropped to zero, and inward and outward currents increased in a non-selective and irreversible manner. The seal was judged to be ruptured.

Single-channel experiments in the outside out configuration

\section{Na-gluconate pipette solution}

After measurements in the whole-cell configuration, the outside out configuration could be established in a small number of cells. A small number of these patches (less than $10 \%$ ) showed channel activity. In four of these patches, large channels could be seen (Fig. 8b). When the chloride concentration was reduced by replacing $130 \mathrm{mmol}^{-1}$ with gluconate, unitary conductance was greatly reduced (Fig. 8c). As described in the "Materials and methods" section, unitary currents could be fitted with the Goldman-Hodgkin-Katz equation for two anions to determine the permeability constants with Na-gluconate solution in the pipette and $\mathrm{NaCl}$ outside, yielding conductance values of $336 \pm 7 \mathrm{pS}$ for chloride and $27 \pm 14 \mathrm{pS}$ for gluconate (normalized to $130 \mathrm{mmol}^{-1}$ symmetrical solutions of chloride and gluconate, respectively; cf. "Materials and methods"; Fig. 12). In one patch, DIDS (100 $\left.\mu \mathrm{mol} \mathrm{l}^{-1}\right)$ was applied, resulting in a reduction of channel activity (Fig. $8 \mathrm{~d}$ ).

Single-channel experiments in the inside out configuration

\section{Symmetrical chloride on both sides of the pipette}

In subsequent experiments, inside out patches were studied in symmetrical $140 \mathrm{mmol}^{-1} \mathrm{NaCl}$ solution. In six patches (out of 58 that showed some form of channel activity and that were recorded), extremely large channel events could be
Fig. 8 Outside out recordings. $a$ Whole-cell recording of cell in $\mathrm{NaCl}$ solution with Na-gluconate in the pipette. $b$ Outside out recording (same cell as in $a$ ). $c$ Outside out recording in symmetrical Na-gluconate solution. $d$ Replacement of bath gluconate with chloride and effect of DIDS $\left(100 \mu \mathrm{mol} \mathrm{l}^{-1}\right.$; same patch as in $c$ )

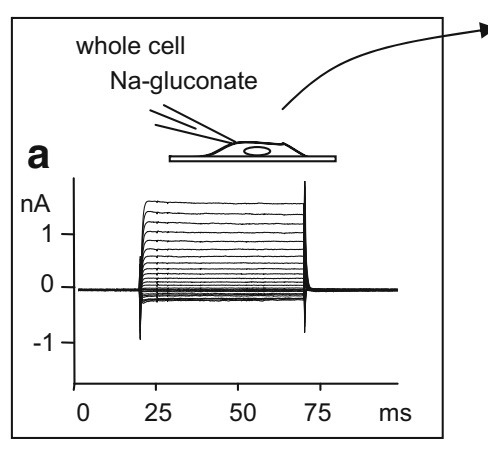

outside out

Na-gluconate $\rightleftharpoons$ bath solution $\mathrm{NaCl} \quad$ Pipette

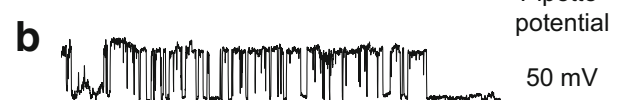

$50 \mathrm{mV}$
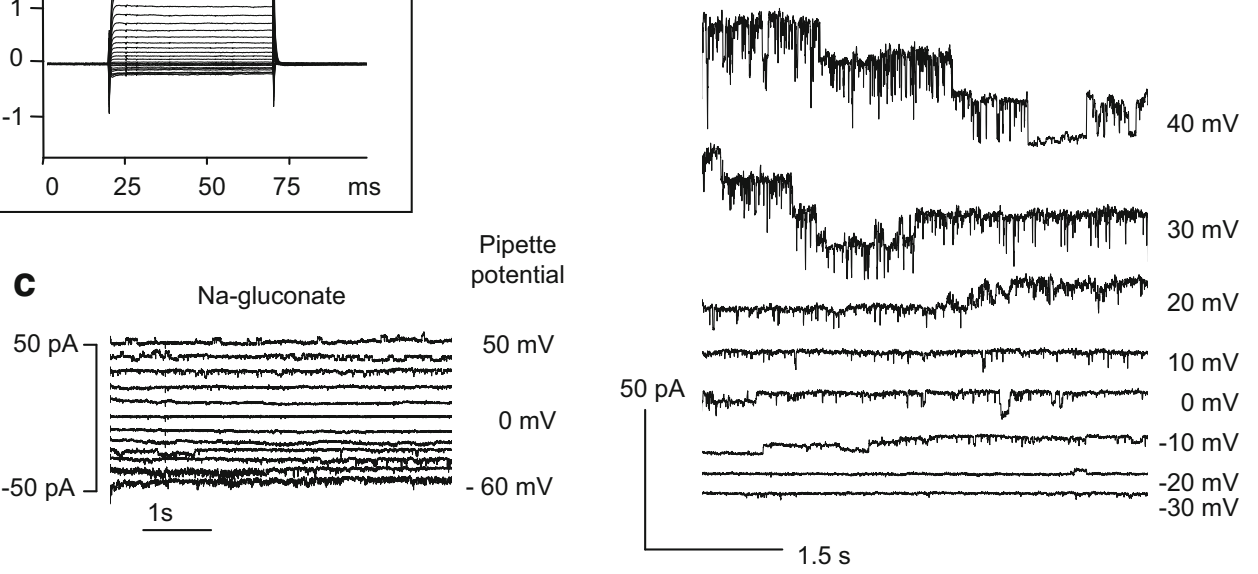

d

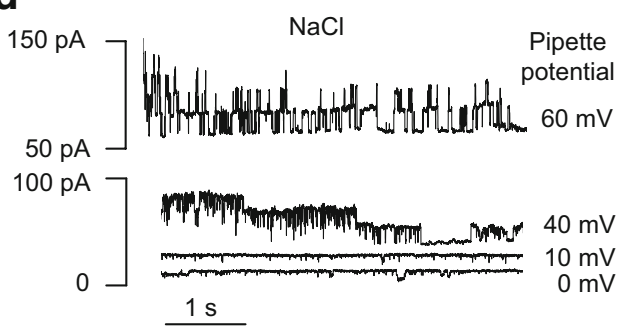

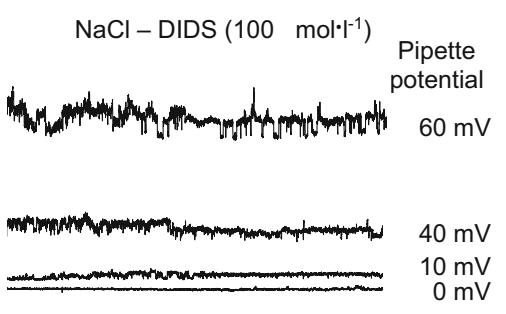


observed with a conductance of $387 \pm 13 \mathrm{pS}$ (140 mmol $\mathrm{l}^{-1}$; Fig. 9a) or $359 \pm 12 \mathrm{pS}$ when normalized to $130 \mathrm{mmol} \mathrm{l}^{-1}$ symmetrical chloride solution (see "Materials and methods"). Similar values were obtained when $130 \mathrm{mmol} \mathrm{l}^{-1} \mathrm{NaCl}$ was replaced by NMDG-Cl on both sides (Figs. 10 and 11a; 332 \pm $7 \mathrm{pS}, n=3, p=0.2$ versus $\mathrm{NaCl}$ ). No channel activity could be seen at $0-\mathrm{mV}$ pipette potential in either configuration.

In summary, the conductance of the channel in $130 \mathrm{mmol}^{-1}$ symmetrical chloride solutions ( $\mathrm{NaCl}$ or NMDG-Cl) was $350 \pm$ $9 \mathrm{pS}(n=9)$.

\section{Asymmetrical conditions}

After replacement of $130 \mathrm{mmol} \mathrm{l}^{-1} \mathrm{NMDG}-\mathrm{Cl}$ by NMDGgluconate in the bath (with NMDG-Cl in the pipette), channel events became visible at $0-\mathrm{mV}$ pipette potential (Fig. 10). The unitary currents increased with a negative but not with positive pipette potential. The currents were plotted against the voltage and fitted with the GoldmanHodgkin-Katz equation as outlined in the "Materials and methods" section, yielding a chloride conductance of $375 \pm$ $30 \mathrm{pS}(n=4)$ and a conductance for gluconate of $57 \pm 18 \mathrm{pS}$ ( $n=4$; Fig. 12). Relative to chloride, the conductance for gluconate was $p\left(\mathrm{Gl}^{-}\right) / p\left(\mathrm{Cl}^{-}\right)=0.16 \pm 0.01$.
After replacement of bath chloride with acetate, channel events could be seen at highly positive levels of pipette potential, suggesting a conductance of the channel for acetate.

\section{NMDG-acetate pipette solution}

In another series of experiments, the conductance for acetate was investigated in a symmetrical $130 \mathrm{mmol}^{-1}$ NMDG-acetate solution, yielding $142 \pm 7$ pS $(n=7$; Figs. 11b, 12), which is significantly higher than the conductance for gluconate but significantly lower than that for chloride $(p<0.001$ for both comparisons). The relative conductance $p\left(\right.$ acetate $-/ p\left(\mathrm{Cl}^{-}\right)=0.41 \pm 0.01$ was comparable with that seen in the whole-cell experiments.

When bath solution was switched to NMDG-Cl solution (with NMDG-acetate in the pipette), the fit yielded a normalized conductance of $226 \pm 9 \mathrm{pS}$ for chloride $(n=3)$. This value was lower than that seen in symmetrical chloride solution $(350 \pm 9 \mathrm{pS} ; p<0.001)$. The conductance of the channel for acetate also appeared to be lowered by the asymmetrical conditions ( $126 \pm 3 \mathrm{pS})$. These results suggest a certain negative interaction between acetate and chloride but certainly no block.
Fig. 9 Inside out recordings. a Current trace from patch in symmetrical solution with $\mathrm{NaCl}$ in the pipette and the bath. In symmetrical solution, no channel events are visible at $0 \mathrm{mV}$. b Current trace from patch with $\mathrm{NaHCO}_{3}$ pipette solution and Na-gluconate in the bath. Small channel events are visible at $0 \mathrm{mV}$ and increase with negative potential
Inside out

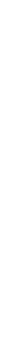
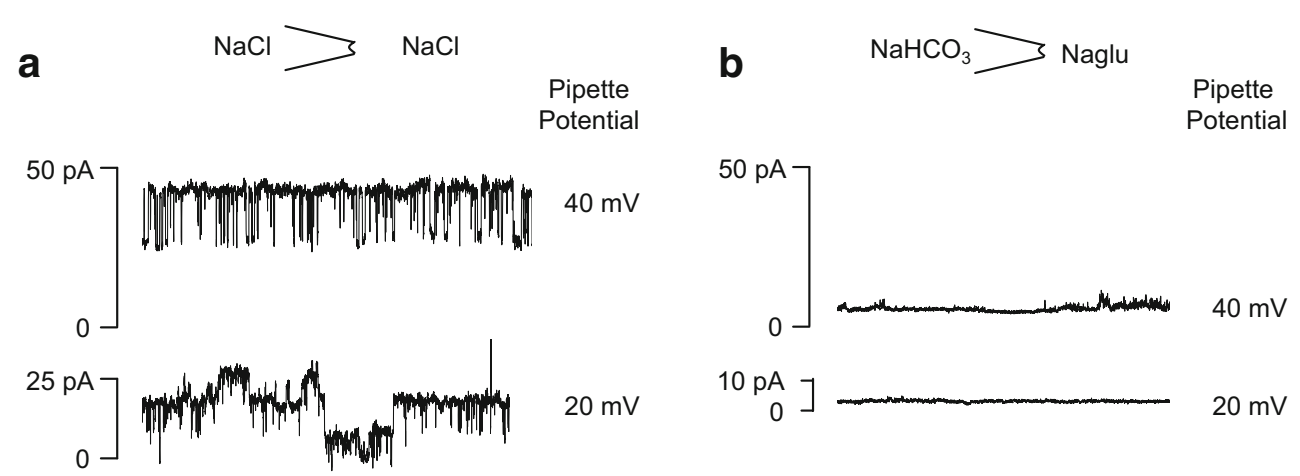

$10 \mathrm{pA}]$

$20 \mathrm{mV}$
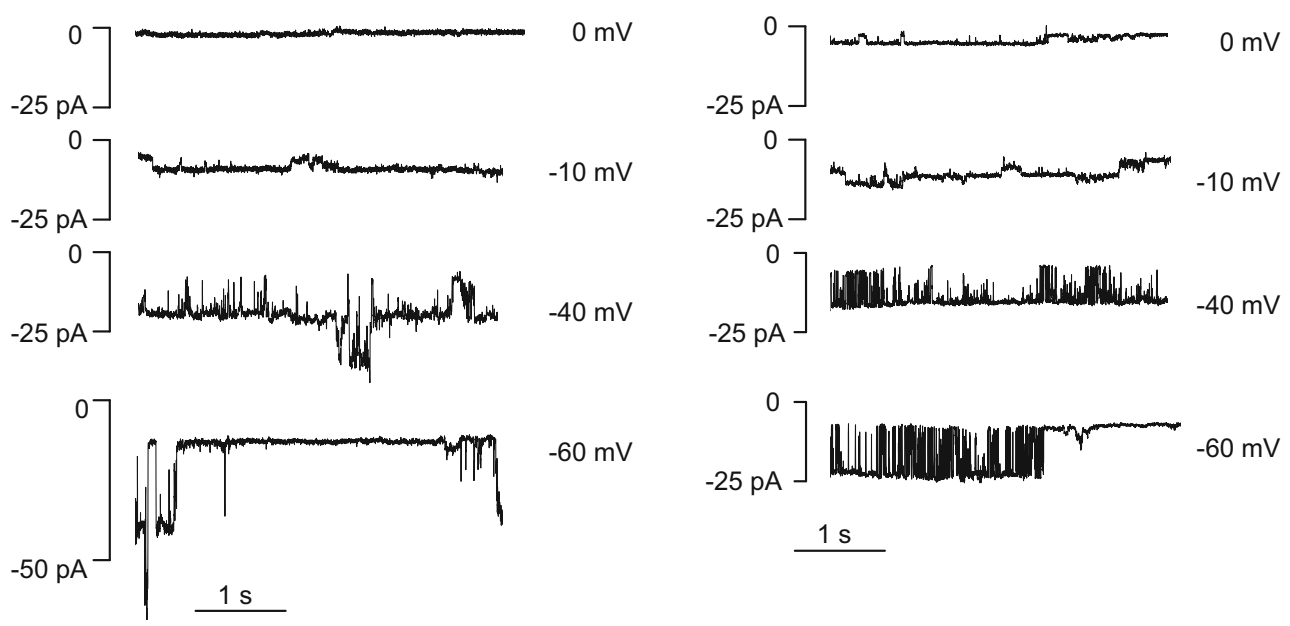
Fig. 10 Inside out recordings. Pipette was filled with NMDG$\mathrm{Cl}$ solution, and currents from the same patch were measured in three different bath solutions The large channel openings at $-60 \mathrm{mV}$ correspond to chloride flowing out of the patch into the bath. At a pipette potential of $0 \mathrm{mV}$, no currents are detectable in symmetrical chloride solution. In acetate and gluconate bath solutions, small channel events reflect the greater conductance of the anion channel for chloride than for either of the two other anions. At $+30 \mathrm{mV}$, channel openings are visible in chloride bath solution and disappear when chloride is replaced by gluconate. In the acetate solution, very small events are visible that may reflect a small influx of acetate into the patch at this potential. At $+60 \mathrm{mV}$, influx of acetate leads to clearly visible single-channel events
Fig. 11 Inside out recordings. a Current trace from patch in symmetrical NMDG-Cl solution. b Current trace from patch in symmetrical NMDG-acetate solution
NMDG-Cl
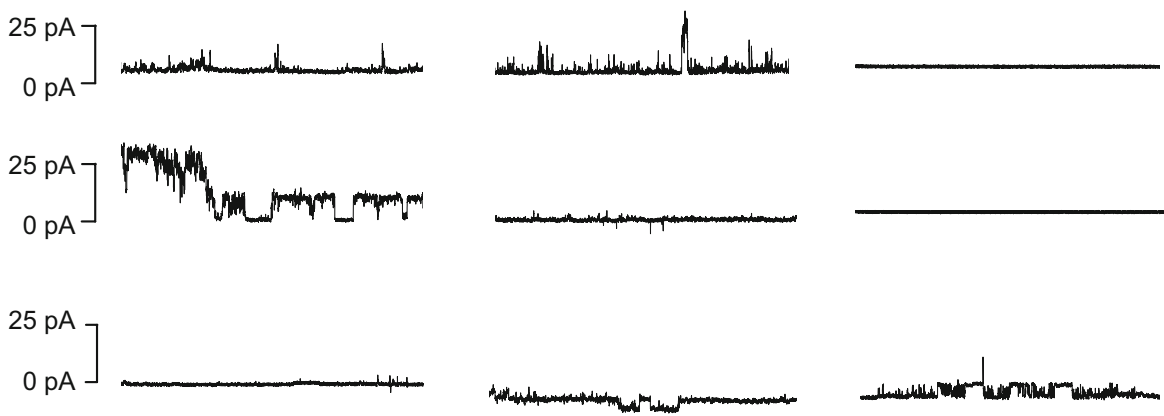

$0 \mathrm{mV}$
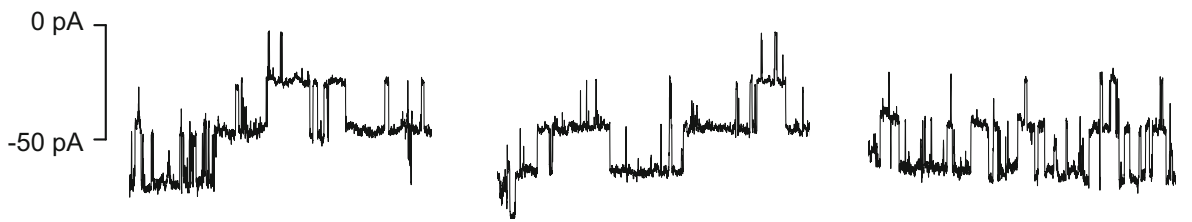
$-60 \mathrm{mV}$
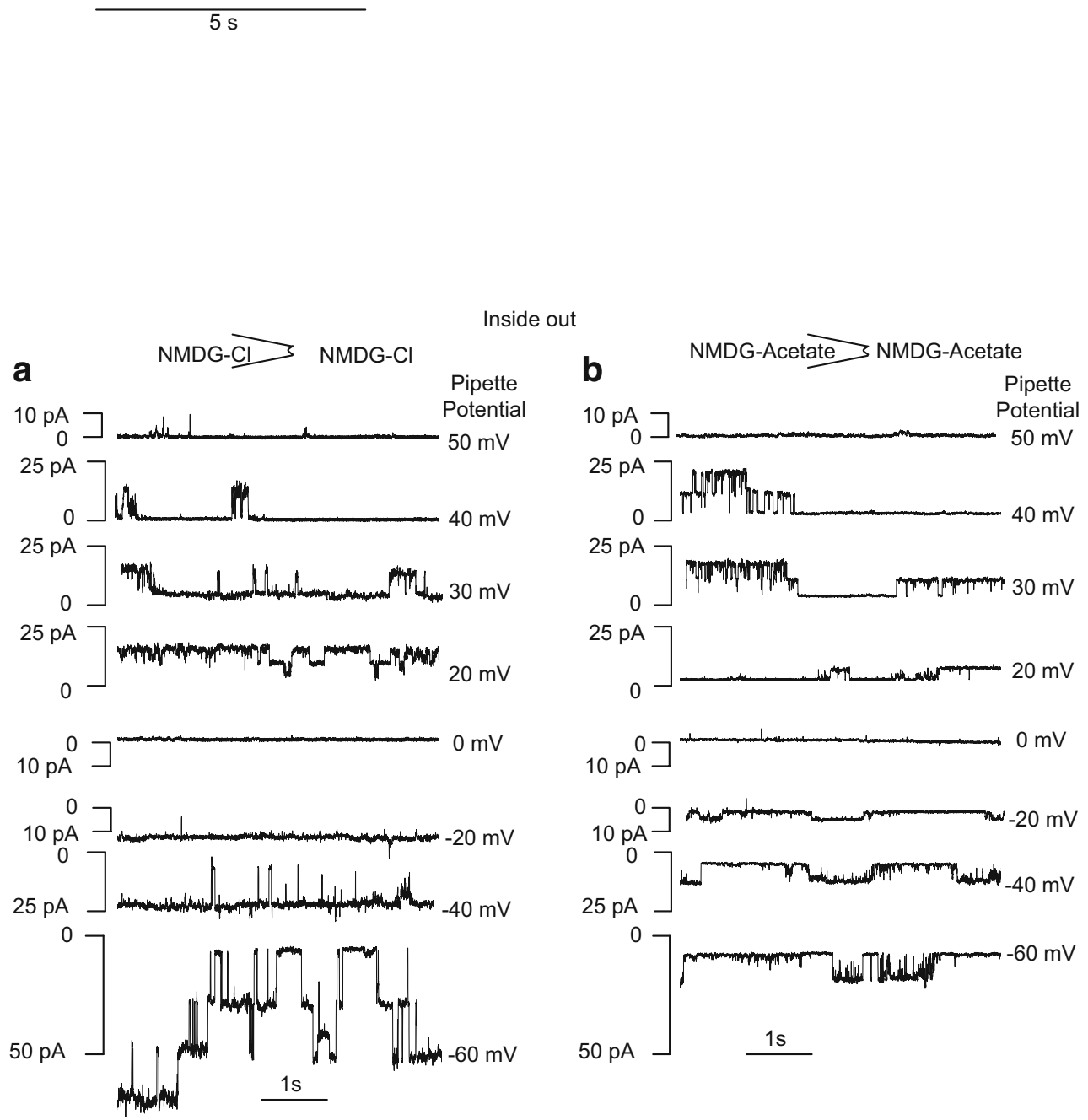
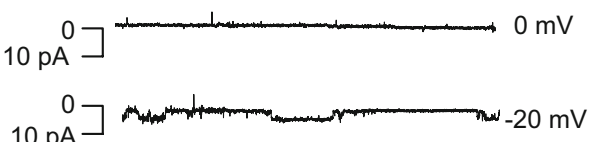

$10 \mathrm{pA}$

$25 \mathrm{pA}$

-

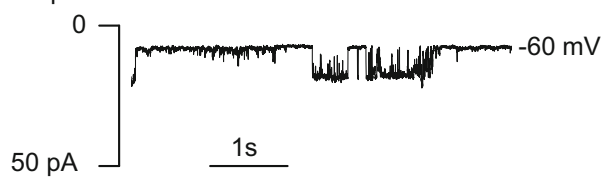


Fig. 12 Data from single-channel experiments. a The means \pm SEM of unitary currents were plotted against the pipette potential and fitted to the Goldman-Hodgkin-Katz equation for three anions (chloride, gluconate, and acetate). All potentials were corrected for liquid junction potential. b Voltage dependence of open probability. Changes in the $\mathrm{NP}_{\mathrm{o}}$ at each potential are given in percent of the mean $\mathrm{m} N P_{\mathrm{o}}$ of each patch for the entire voltage range (see text). The data were fitted by using a modification of classical gating theory (see text) a Current-voltage relationship of single-channel currents

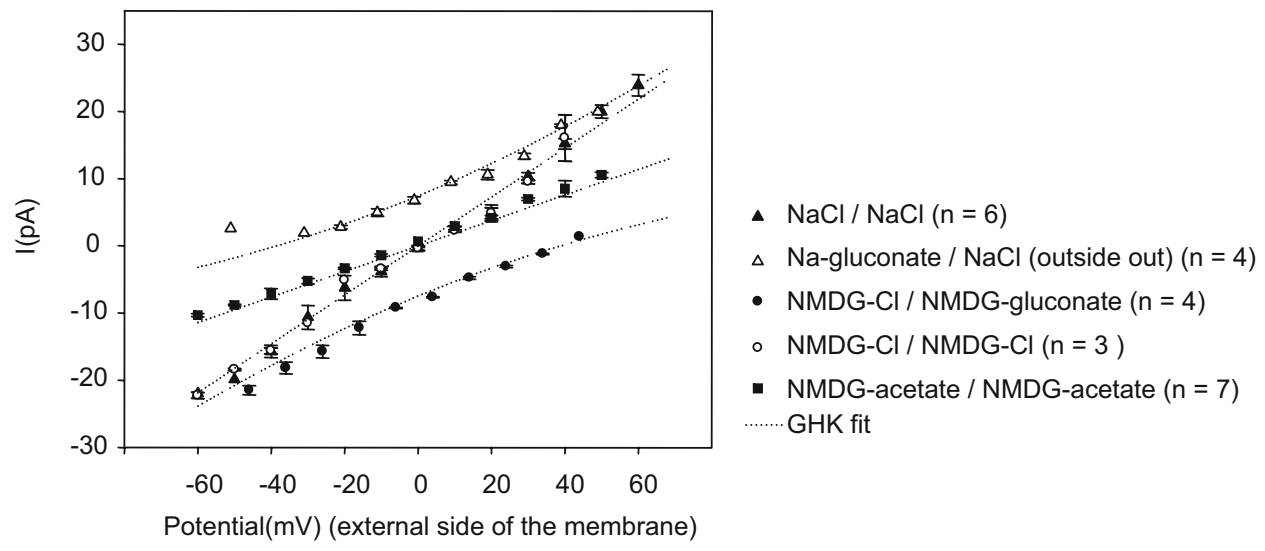

b

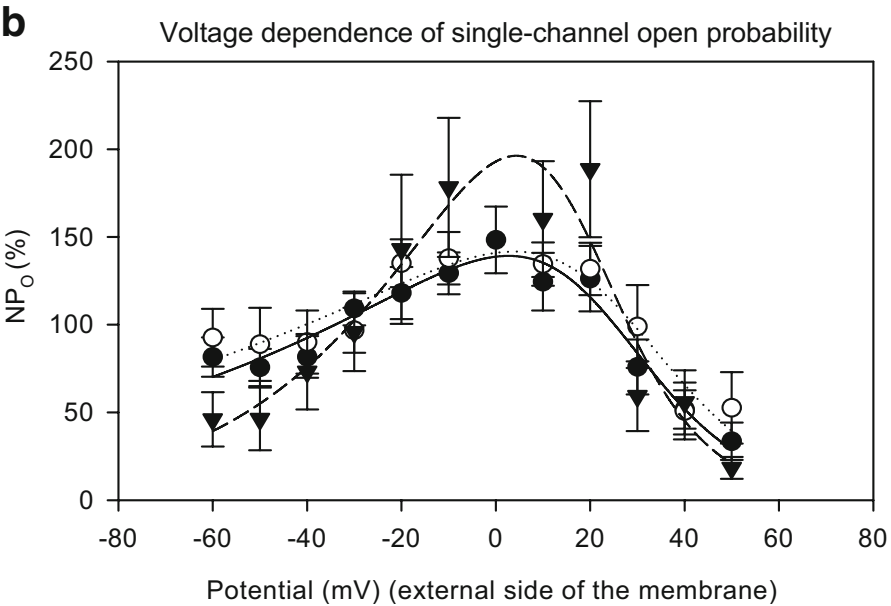

all measurements symmetrical chloride symmetrical acetate all measurements symmetrical chloride symmetrical acetate

\section{$\mathrm{NaHCO}_{3}$ pipette solution}

When the pipette was filled with $\mathrm{NaHCO}_{3}$ solution and superfused with Na-gluconate, channel activity could be observed in two patches. A fit for both anions yielded a conductance for $\mathrm{HCO}_{3}{ }^{-}$of $120 \pm 8 \mathrm{pS}$ and for gluconate of $62 \pm 8 \mathrm{pS}$ (Fig. 9b).

Voltage dependence of open probability

The single-channel measurements showed that chloride channels in ruminal epithelial cells clearly existed in clusters and tended to open in bursts. Patches were sometimes silent for no apparent reason before channels began to open, usually many at a time. Since the random bursts made it practically impossible to estimate the true number of channels in a patch, channel activity was calculated from the product $N P_{\mathrm{o}}$, in which $N$ is the number of channels and $P_{\mathrm{o}}$ is single-channel open probability. The time integral of current divided by the product of mean single-channel current and the time of recording is equal to $N P_{\mathrm{o}}$ [35]. Because of the overall variability of $N P_{\mathrm{o}}$, no significant differences emerged between patches in different solutions at a given potential level. In an attempt to maximize observation time and thus to eliminate the distorting influence of channel bursts, voltage was disregarded, and a mean value $\left(\mathrm{m} N P_{\mathrm{o}}\right)$ was calculated from all the $N P_{\mathrm{o}}$ values of all sweeps (from -60 to $+50 \mathrm{mV}$ ) performed on a particular patch in a given configuration of internal and external pipette solution. For a given patch, this mean value $(\mathrm{mNP})$ tended to remain relatively stable over time and appeared to reflect the number of channels in a given patch. However, no clearly significant effects of solution on channel open probability could be demonstrated.

If, in a given patch, $N P_{\mathrm{o}}$ reflects the number of open channels at a particular voltage and if $\mathrm{mNP}$ o (the mean value of $N P_{\mathrm{o}}$ over the entire voltage range) is proportional to the number of channels in the patch, then the relationship $N P_{\mathrm{o}} / \mathrm{m} N P_{\mathrm{o}}$ should be proportional to the open probability of the channel at a given voltage. Figure $12 \mathrm{~b}$ shows the change of $\mathrm{NP}_{\mathrm{O}}$ (expressed as a percent of the $\mathrm{mNP} P_{\mathrm{o}}$ value for each patch) with the applied voltage $E$ (external side negative). $N P_{\mathrm{o}} / \mathrm{m} N P_{\mathrm{o}}$ was clearly voltage dependent.

To fit these data, we have developed a simple variation of a classical gating model [36] (see "Materials and 
methods" section, Eq. 4). This model assumes that a charged particle lies within the channel pore and obstructs it at highly positive or highly negative voltages, thus leading to the bell-shaped voltage dependence of open probability.
Since the number of channels in the patch is unknown, a voltage-independent scaling factor $\lambda$ (reflecting the number of channels in the patch) was introduced so that Eq. 4 of the "Materials and methods" section becomes:

$$
N P_{\mathrm{o}}(\%)(E)=\lambda \cdot P_{\mathrm{o}} /\left(\mathrm{P} 1_{\mathrm{c}}+P_{\mathrm{o}}+\mathrm{P} 2_{\mathrm{c}}\right)=\lambda \cdot 1 /\left[\exp \left(-\left(w-\alpha \cdot n \cdot E \cdot q_{\mathrm{e}} /\left(k_{\mathrm{b}} \cdot T\right)\right)\right)+1+\exp \left(-\left(v+\beta \cdot n \cdot E \cdot q_{\mathrm{e}} /\left(k_{\mathrm{b}} \cdot T\right)\right)\right)\right]
$$

SigmaPlot software was used to fit the data to this function for the scaling factor $\lambda$, for the fractional dislocations of the gating charge $\alpha$ and $\beta$, for the voltageindependent energies $w$ and $v$ and, for the gating charge $n$ (see "Materials and methods"). Figure 12b shows the resulting curves. Values for the gating charge $n$ were remarkably consistent, yielding a gating charge $n$ of 2.4 (from the fit of all measurements), with the fit for symmetrical chloride solutions yielding a somewhat lower value (2.2) than that for the symmetrical acetate solution (2.8).

Values for $\lambda$ were 1,263 (all measurements), 1,063 (symmetrical chloride), and 508 (acetate), suggesting that the number of channels per patch happened to be lowest on the days on which the acetate pipette solution was used. Use of $\lambda$ and the measured $N P_{\mathrm{o}}$ 's at $-60 \mathrm{mV}$ allows a rough estimate to be calculated for the average number of channels in the patches used for the fit, namely $16 \pm 3$ channels. The data for the fractional dislocations of the gating charge in the pore showed no dependence on solution and were $\alpha: 0.80,0.81$, and $0.82 ; \beta: 0.17,0.15$ and 0.13 (all measurements, symmetrical chloride and symmetrical acetate, respectively). The voltage-independent energies were $w:-0.16,0.25$, and 1.10 and $v:-1.94,-1.73$, and -0.26 . The high fluctuation in the values for $w$ and $v$ may reflect the finding that voltage-independent energies were dwarfed by the voltage-dependent energies in the high voltage ranges where the signal/noise ratio tended to be most reliable.

\section{Discussion}

The data presented in this study clearly show that cultured cells of the ruminal epithelium express large-conductance anion channels with the ability to transport not only chloride but also $\mathrm{HCO}_{3}{ }^{-}$and acetate. Chloride conductances dominate the whole-cell currents of $90 \%$ of the cells investigated. Since the conductance of the channel is so large, channel density should be low. Accordingly, the vast majority $(>90 \%)$ of excised patches show no chloride channels. Interestingly, those patches with channel activity tend to show clusters of channels.

The relative conductances for the various anions were remarkably similar in the whole-cell and single-channel modes. In single-channel experiments, conductance was significantly lower in asymmetrical situations with acetate on one side and chloride on the other side, suggesting some negative interaction. Even in the presence of two different ions, the overall conductance of the channel remained high, and there was no sign of total block.

The channel was highly sensitive to DIDS $\left(1 \mathrm{mmol} \mathrm{l}^{-1}\right)$ and less sensitive to niflumic acid $\left(100 \mu \mathrm{mol} \mathrm{l}^{-1}\right), 5$-nitro-2(3-phenylpropyl-amino) benzoic acid $\left(50 \mu \mathrm{mol} \mathrm{l}^{-1}\right)$, and $p$ chloromercuribenzoate $\left(1 \mathrm{mmol} \mathrm{l}^{-1}\right)$. The channel was insensitive to nitrate $\left(10 \mathrm{mmol} \mathrm{l}^{-1}\right)$, to furosemide $\left(100 \mu \mathrm{mol} \mathrm{l}^{-1}\right)$, and to flufenamic acid $\left(2 \times 10^{-5} \mu \mathrm{mol} \mathrm{l}^{-1}\right)$.

DIDS rapidly and reliably reduced the current at positive potentials not only in $\mathrm{NaCl}$ containing solutions but also in solutions with $\mathrm{NaNO}_{3}, \mathrm{NaHCO}_{3}$, or Na-acetate, reflecting a reduction of the flux of anions into the cell. Interestingly, DIDS did not affect reversal potential when cells were filled with Na-gluconate solution. We initially expected a drop in the relative conductance for anions to increase the relative conductance for sodium, resulting in a depolarization of the cells following a block of the anion conductance. However, the sodium conductance of ruminal epithelial cells is rather low in the presence of $\mathrm{Mg}^{2+}[34,37]$ and may have a minor influence on membrane potential. When the contribution of sodium to total membrane potential was increased by filling the cells with an NMDG-gluconate solution and superfusing them with a Na-acetate solution, DIDS had a significant depolarizing effect on the reversal potential. Since the reversal potential is higher under these conditions, the anion channel may also have shown greater responsiveness to DIDS, which is known for the voltage dependence of its blocking properties [38]. Likewise, $p$-mercuribenzoate had clear effects on membrane potential that demonstrate that it blocks a conductance for acetate, with no impact on sodium current.

In addition to the finding that ruminal epithelial cells express anion channels, we provide evidence that exposure 
to acetate enhances both cationic and anionic conductances of some but not all cells treated (Fig. 5). In cells where it occurs, this rise in conductance increases with the time of exposure to acetate. This induction of current may well reflect a minor swelling of the cells below the level of detection. However, and despite buffering of the pipette solution, it appears equally possible that the currents were induced by changes in cytosolic pH. Like other cells [39], cultured ruminal epithelial cells transiently become acidic when exposed to acetate [40].

In this context, it should be mentioned that the influx of acetate through an anion channel is limited by the membrane potential [22]. For this reason, when (unclamped) cells are surrounded by a medium containing acetate, the influx of the undissociated acid will usually predominate. Modulation of the membrane potential by induction of $\mathrm{Na}^{+}$and $\mathrm{K}^{+}$ conductances should have great impact on the influx of acetate through the channel and may play a role in cell homeostasis.

The general capability of anion channels to transport relatively large anions is well documented and even includes ATP [41] and negatively charged amino acids such as taurine [42] and glutamate [43]. Likewise, the direct [44-46] or indirect [47] stimulatory effect of SCFAs on cationic or anionic conductances has been the object of a number of studies.

In contrast, few studies have systematically studied the permeability of anion channels for the anions of SCFA. The cystic fibrosis transmembrane conductance regulator (CFTR) has been shown to have a measurable conductance for acetate and propionate in Chinese hamster ovary cells [48], and $\mathrm{Ca}^{2+}$-activated $\mathrm{Cl}^{-}$channels of the Xenopus oocyte conduct acetate [49]. However, both CFTR and the channels of the CLC group typically show conductances that are an order of magnitude below those observed in this study. Channels from the group of volume-regulated anion channels (VRAC) are known for their ability to conduct organic osmolytes and thus appear promising candidates, but again, the conductances of VRAC (typically 50-90 pS) $[41,50]$ are much lower than those of the ruminal channel investigated in this study. A number of high-conductance chloride channels with conductances of 250-430 pS have been measured in native tissues [51-54], and largeconductance anion channels (195 pS in symmetrical $160 \mathrm{mmol} \mathrm{l}^{-1} \mathrm{NaCl}$ ) have been demonstrated to conduct acetate and butyrate in the gastrointestinal nematode Ascaris suum [55]. However, the molecular identity of these channels is not clear.

Chloride channels from astrocytes and from neuroblastoma cells show large conductances, DIDS sensitivity, and a bell-shaped voltage dependence of open probability [56, 57]. These channels have been suggested to be identical to the voltage-dependent anion channel of the outer mitochondrial membrane (VDAC) [58]. At voltages greater than $30 \mathrm{mV}$ or smaller than $-30 \mathrm{mV}$, a positively charged particle within the selectivity filter of the VDAC channel is dislocated so that the pore becomes impermeable to anions [59]; instead, the channel becomes cation selective. When fitted with a two-state model for positive and negative potentials separately, the gating charge of the VDAC voltage sensor is found to be around $4[36,60]$. Conversely, the ruminal anion channel continues to show activity at voltages exceeding $\pm 60 \mathrm{mV}$, reflecting a much lower gating charge (of below 1 if conventional gating models are applied). In addition, the ruminal anion channel is highly selective for anions over cations. Thus, any relationship to the VDAC of the mitochondrial membrane is likely to be remote.

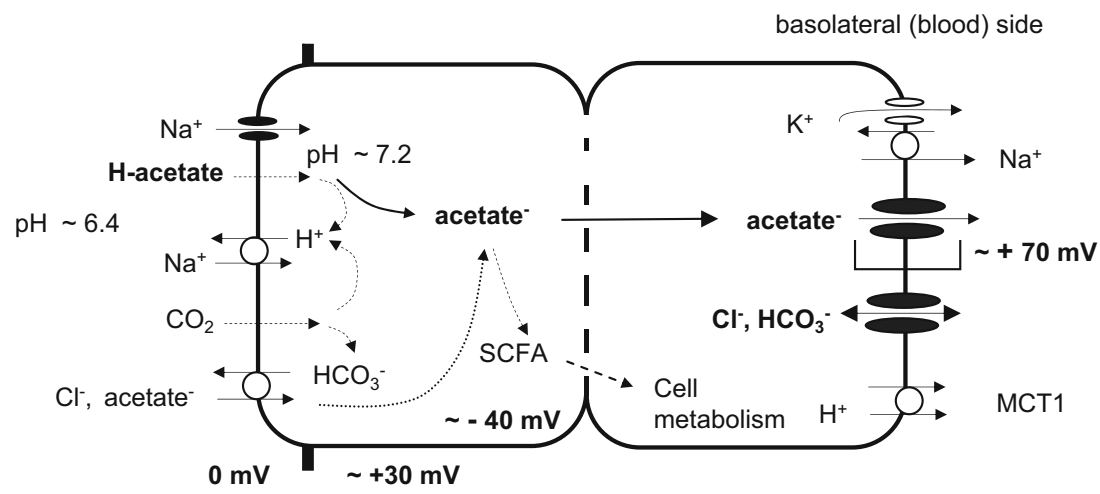

Fig. 13 Simplified model of ruminal acetate transport. Apically, uptake of acetate is mediated by lipid diffusion from the slightly acidic mucosal side of the ruminal fluid and by an anion exchanger. A large-conductance anion channel is proposed as a major basolateral efflux route. The potential difference generated by the $\mathrm{Na}-\mathrm{K}-\mathrm{ATP}$ ase and $\mathrm{K}+$ efflux across the basolateral membrane serves as a driving force, thus minimizing the accumulation of acetate within the cell. The direction of chloride and bicarbonate movements through the channel can be expected to vary with the electrochemical gradient, depending on ruminal concentrations and cellular metabolism. Organic anions that do not permeate through the pore of this channel can leave via MCT1 
For the reasons outlined above, the molecular identity of the channel will be difficult to determine and, thus, the localization of the channel in the tissue by immunohistochemical methods will be problematic. The origin of the cells does not provide useful clues, either. While cultured ruminal epithelial cells are derived from the replicating cells of the stratum basale, they typically differentiate to express both apical and basolateral transport proteins of the ruminal epithelium [26, 29, 34, 61]. Nevertheless, our present knowledge from studies on intact tissue makes it possible to postulate a role for this channel in the basolateral efflux of anions.

Current models consider the ruminal epithelium as a multi-layered functional syncytium with the stratum granulosum as the cell layer separating the apical from the basolateral side [62]. A basolateral electrogenic pathway for anions is clearly necessary to balance the fluxes of sodium and chloride with the short circuit current in Ussing chamber studies of the ruminal epithelium [26]. According to the current model of ruminal transport, apical uptake of $\mathrm{Na}^{+}$primarily occurs in an electroneutral manner via the sodium-proton-exchanger (NHE), coupled to electroneutral uptake of $\mathrm{Cl}^{-}$via an anion exchanger in exchange for $\mathrm{HCO}_{3}{ }^{-}$. Basolateral efflux of $\mathrm{Na}^{+}$, conversely, occurs via the $\mathrm{Na}^{+}-\mathrm{K}^{+}$-ATPase and is electrogenic. This model of transport is not workable unless either apical (electrogenic) secretion of cations or the basolateral (electrogenic) efflux of anions occurs. Since apical potassium secretion of the rumen is marginal under the low potassium conditions of in vitro studies [63], basolateral efflux of chloride (or other anions) via an electrogenic pathway appears mandatory and is supported by data from the intact epithelium [26, 27]. Careful analysis of flux data reveals an "anion gap" between the fluxes of sodium and chloride on the one hand and the short circuit current on the other. This anion gap persists in the absence of $\mathrm{HCO}_{3}{ }^{-}$, is particularly noticeable at low mucosal $\mathrm{pH}$, and might be satisfactorily explained by the assumption of an efflux of SCFA as anions across the basolateral side [26]. This observation has provided the stimulus for the current investigation.

The presently accepted model of ruminal transport of SCFA is transcellular and involves both electroneutral apical permeation of the undissociated form of the SCFA via lipid diffusion $[64,65]$ and the uptake of the dissociated anion via a DIDS-sensitive anion exchanger [18, 20, 28, 65, 66]. Conversely, paracellular transport appears to be marginal since an applied electrical potential shows no effect on the fluxes of SCFA across the ruminal epithelium $[17,28]$.

Basolateral efflux of monocarboxylic acids is thought to occur via the MCT1 located in the basolateral membrane $[21,24,25]$. A recent study [21] has demonstrated an inhibitory effect of a basolateral application of $p$-chloro- mercuribenzoate on acetate transport across the caprine rumen in vivo and in vitro. Whereas this effect may be attributable, at least in part, to a block of the MCT1, our data suggest that at the concentrations used [21], $p$ chloromercuribenzoate also blocks the large-conductance anion channel of ruminal epithelial cells. The interaction of mercurial derivatives with anion channels is well documented [67, 68].

From a theoretical point of view, the expression of acetate-permeable channels in the basolateral membrane of the rumen should be highly advantageous to the animal since the considerable electrical gradient of some $-70 \mathrm{mV}$ (blood-side positive) serves as a driving force for the efflux of acetate from the cells across the basolateral membrane (Fig. 13). Transport rates through channels are typically several orders of magnitude higher than those of transporters [33], and, thus, a relatively small number of channels should be able to mediate a large amount of efflux. The accumulation of acetate within the cells should endanger their survival not only through the disruption of cellular volume regulation but also by shifting cytosolic buffering toward the $\mathrm{p} K$ value of acetic acid $(\approx 4.76)$. Under the extreme conditions found in the rumen, where acetate concentration can easily exceed $70 \mathrm{mmol} \mathrm{l}^{-1}$ and the total concentration of SCFA typically reaches values of over $100 \mathrm{mmol} \mathrm{l}^{-1}$ [4], a basolateral, acetate-conducting channel would therefore greatly enhance the total transporting capacity of the tissue.

In summary, we provide evidence that cells of the ruminal epithelium in culture express an anion channel with a large conductance for chloride, nitrate, $\mathrm{HCO}_{3}{ }^{-}$, and acetate. We suggest that, physiologically, this channel plays a role in the basolateral permeation of anions across the ruminal epithelium.

Acknowledgments The help of Gabriele Kiselowski in preparing the cells is gratefully acknowledged. We also thank the Deutsche Forschungsgemeinschaft (DFG STU 258/4-1) and the Margarete Marcus Charity for their financial support. Thanks also to E. Skadhauge for sharing his thoughts on ruminal transport of acetate.

\section{Appendix}

In the following, it will be shown that if transport of SCFA across the apical and the basolateral membrane is assumed to occur via passive diffusion only, equilibrium calculations predict an accumulation of SCFA within the cells not only of tissues bathed on all sides by a SCFA-containing solution [22] but also within a transporting epithelium in a gradient of SCFA.

We will assume that on the mucosal side, the total concentration of the SCFA (dissociated and undissociated: $[\mathrm{SCFA}]_{\mathrm{m}}{ }^{\text {tot }}$ ) remains constant throughout, whereas basolat- 
erally, the concentration remains zero (e.g., removal by the portal circulation). Mucosal uptake of the protonated, undissociated SCFA $\left(\mathrm{J}(\mathrm{HSFA})_{\mathrm{m}}\right)$ into the cell will depend on the concentration gradient between the undissociated SCFA on the mucosal side $\left([\mathrm{HSCFA}]_{\mathrm{m}}\right)$ and the cytosol ([HSCFA $]_{\text {cyt }}$ ) multiplied by a diffusion constant $C_{1}$ : $J(\mathrm{HSCFA})_{\mathrm{m}}=C_{1}\left([\mathrm{HSCFA}]_{\mathrm{m}}-[\mathrm{HSCFA}]_{\mathrm{cyt}}\right)$. By analogy, efflux from the basolateral side will be $J(\mathrm{HSCFA})_{\mathrm{s}}=C_{2}$ ([HSCFA $]_{\text {cyt }}$ ), where $C_{2}$ is the constant describing the efflux of undissociated SCFA across the basolateral membrane. The cytosolic concentration ([HSCFA $]_{\text {cyt }}$ ) will rise until steadystate conditions are reached and apical influx equals basolateral efflux:

$$
\begin{aligned}
J(\text { HSCFA })_{\mathrm{m}} & =C_{1} \cdot\left([\mathrm{HSCFA}]_{\mathrm{m}}-[\text { HSCFA }]_{\mathrm{cyt}}\right) \\
& =J(\mathrm{HSCFA})_{\mathrm{S}}=C_{2} \cdot\left([\text { HSCFA }]_{\mathrm{cyt}}\right)
\end{aligned}
$$

leading to:

$$
[\mathrm{HSCFA}]_{\mathrm{cyt}}=C_{1} /\left(C_{1}+C_{2}\right) \cdot[\mathrm{HSCFA}]_{\mathrm{m}} .
$$

The concentration of the undissociated SCFA $[\mathrm{HSCFA}]_{\mathrm{m}}$ can be calculated from the total mucosal concentration $\left([\mathrm{SCFA}]_{\mathrm{m}}{ }^{\text {tot }}\right)$, the mucosal $\mathrm{pH}(\mathrm{pH}(\mathrm{m}))$, and the dissociation constant $(\mathrm{p} K)$ by using the Henderson-Hasselbalch equation:

$$
[\mathrm{HSCFA}]_{\mathrm{m}}=[\mathrm{SCFA}]_{\mathrm{m}}^{\text {tot }} /\left(10^{\mathrm{pH}(\mathrm{m})-\mathrm{p} K}+1\right) .
$$

Once in the cell and depending on the $\mathrm{pH}$ of the cytosol $(\mathrm{pH}(\mathrm{cyt}))$, a certain fraction of the undissociated SCFA will dissociate and accumulate until an equilibrium state between dissociation and formation is reached, leading to a total concentration of SCFA within the cytosol of:

$$
\begin{aligned}
{[\mathrm{SCFA}]_{\mathrm{cyt}}{ }^{\mathrm{tot}}=} & {[\mathrm{HSCFA}]_{\mathrm{cyt}} \cdot\left(10^{\mathrm{pH}(\mathrm{cyt})-\mathrm{p} K}+1\right) } \\
= & C_{1} /\left(C_{1}+C_{2}\right) \cdot[\mathrm{HSCFA}]_{\mathrm{m}} \cdot\left(10^{\mathrm{pH}(\mathrm{cyt})-\mathrm{p} K}+1\right) \\
= & C_{1} /\left(C_{1}+C_{2}\right) \cdot[\mathrm{SCFA}]_{\mathrm{m}}^{\text {tot }} \cdot\left(10^{\mathrm{pH}(\mathrm{cyt})-\mathrm{p} K}+1\right) \\
& /\left(10^{\mathrm{pH}(\mathrm{m})-\mathrm{p} K}+1\right)
\end{aligned}
$$

For acetic acid $(\mathrm{p} K=4.76)$ and by using $\mathrm{pH}(\mathrm{cyt}) \approx 7.4$ [24] and a typical ruminal $\mathrm{pH}(\mathrm{m}) \approx 6.4$, we get:

$$
[\mathrm{SCFA}]_{\mathrm{cyt}}^{\mathrm{tot}}=9.8 \cdot C_{1} /\left(C_{1}+C_{2}\right) \cdot[\mathrm{SCFA}]_{\mathrm{m}}{ }^{\text {tot }} \text {. }
$$

If we make the straightforward assumption that the apical membrane is as permeable to acetate as the basolateral membrane $\left(C_{1}=C_{2}\right)$, the accumulation of acetate will reach a catastrophic dimension of $300 \mathrm{mmol} \mathrm{l}^{-1}$ at a ruminal concentration of $60 \mathrm{mmol}^{-1}$. Even if we were to assume that for some reason basolateral permeability $C_{2}$ of the epithelium for acetate were nine times higher than that of the apical membrane $\left(C_{1}\right)$, acetate should accumulate within the ruminal epithelium to the level found within the rumen $\left(\approx 60 \mathrm{mmol}^{-1}\right)$, application of a multilayer model creates even greater problems for the apical layer of cells, as does the influx of acetate anions via electroneutral exchange. In the model presented in this paper, the electrical gradient serves as a driving force for the efflux of acetate through a large-conductance channel in the basolateral membrane and can thus mediate efflux of SCFA at low cytosolic concentrations. This transport model is thus more able to meet the requirements of cell homeostasis than models assuming an efflux driven by concentration gradients only.

\section{References}

1. Cummings JH, Pomare EW et al (1987) Short chain fatty acids in human large intestine, portal, hepatic and venous blood. Gut 28 (10):1221-1227

2. Holtug K, Rasmussen HS et al (1992) An in vitro study of shortchain fatty acid concentrations, production and absorption in pig (Sus scrofa) colon. Comp Biochem Physiol Comp Physiol 103 (1):189-197

3. Sellin JH (1999) SCFAs: the enigma of weak electrolyte transport in the colon. News Physiol Sci 14:58-64

4. Bergman EN, Reid RS et al (1965) Interconversions and production of volatile fatty acids in the sheep rumen. Biochem J 97(1):53-58

5. Gäbel G, Aschenbach JR et al (2002) Transfer of energy substrates across the ruminal epithelium: implications and limitations. Anim Health Res Rev 3(1):15-30

6. Phillipson AT (1949) Absorption of acetate from the rumen of sheep. J Physiol 109(1-2):Proc 31

7. Masson MJ, Phillipson AT (1951) The absorption of acetate, propionate and butyrate from the rumen of sheep. J Physiol 113 (2-3):189-206

8. Siciliano-Jones J, Murphy MR (1989) Production of volatile fatty acids in the rumen and cecum-colon of steers as affected by forage:concentrate and forage physical form. J Dairy Sci 72 (2):485-492

9. Bergman EN (1990) Energy contributions of volatile fatty acids from the gastrointestinal tract in various species. Physiol Rev 70 (2):567-590

10. Peters JP, Shen RY et al (1992) Disappearance of acetic acid from the bovine reticulorumen at basal and elevated concentrations of acetic acid. J Anim Sci 70(5):1509-1517

11. Engelhardt Wv, Hauffe R (1975) Funktionen des Blättermagens bei kleinen Hauswiederkäuern. Zentralbl Veterinarmed A 22:363375

12. Thorlacius SO, Lodge GA (1973) Absorption of steam-volatile fatty acids from the rumen of the cow as influenced by diet, buffers, and pH. Can J Anim Sci 53:279-288

13. Weigand E, Young JW et al (1972) Extent of butyrate metabolism by bovine ruminoreticulum epithelium and the relationship to absorption rate. J Dairy Sci 55(5):589-597

14. Kristensen NB, Gabel G et al (2000) Portal recovery of shortchain fatty acids infused into the temporarily-isolated and washed reticulo-rumen of sheep. Br J Nutr 84(4):477-482

15. Kristensen NB, Harmon DL (2004) Splanchnic metabolism of volatile fatty acids absorbed from the washed reticulorumen of steers. J Anim Sci 82(7):2033-2042 
16. Weigand E, Young JW et al (1972) Extent of propionate metabolism during absorption from the bovine ruminoreticulum. Biochem J 126(1):201-209

17. Stevens CE, Stettler BK (1966) Transport of fatty acid mixtures across rumen epithelium. Am J Physiol 211(1):264-271

18. Kramer T, Michelberger T et al (1996) Absorption of short-chain fatty acids across ruminal epithelium of sheep. J Comp Physiol [B] 166(4):262-269

19. Gäbel $G$, Butter $H$ et al (1999) Regulatory role of cAMP in transport of $\mathrm{Na}+, \mathrm{Cl}-$ and short-chain fatty acids across sheep ruminal epithelium. Exp Physiol 84(2):333-345

20. Sehested J, Diernaes L et al (1999) Ruminal transport and metabolism of short-chain fatty acids (SCFA) in vitro: effect of SCFA chain length and pH. Comp Biochem Physiol A Mol Integr Physiol 123(4):359-368

21. Kirat D, Masuoka J et al (2006) Monocarboxylate transporter 1 (MCT1) plays a direct role in short-chain fatty acids absorption in caprine rumen. J Physiol 576(Pt 2):635-647

22. Roos A (1975) Intracellular $\mathrm{pH}$ and distribution of weak acids across cell membranes. A study of D- and L-lactate and of DMO in rat diaphragm. J Physiol 249(1):1-25

23. Jackson M (1974) Intestinal SCFA transport. In: Smyth DH, Manson LA (eds) Intestinal absorption. Plenum, New York, pp 673-709

24. Müller F, Huber K et al (2002) Transport of ketone bodies and lactate in the sheep ruminal epithelium by monocarboxylate transporter 1. Am J Physiol Gastrointest Liver Physiol 283(5): G1139-G1146

25. Graham C, Gatherar I et al (2007) Expression and localization of monocarboxylate transporters and sodium/proton exchangers in bovine rumen epithelium. Am J Physiol Regul Integr Comp Physiol 292(2):R997-R1007

26. Abdoun K, Stumpff F et al (2005) Modulation of electroneutral $\mathrm{Na}$ transport in sheep rumen epithelium by luminal ammonia. Am J Physiol Gastrointest Liver Physiol 289(3):G508-G520

27. Leonhard-Marek S, Breves $\mathrm{G}$ et al (2006) Effect of chloride on $\mathrm{pH}$ microclimate and electrogenic $\mathrm{Na}+$ absorption across the rumen epithelium of goat and sheep. Am J Physiol Gastrointest Liver Physiol 291(2):G246-G252

28. Sehested J, Diernaes L et al (1999) Transport of butyrate across the isolated bovine rumen epithelium-interaction with sodium, chloride and bicarbonate. Comp Biochem Physiol A Mol Integr Physiol 123(4):399-408

29. Schweigel M, Lang I et al (1999) $\mathrm{Mg}(2+)$ transport in sheep rumen epithelium: evidence for an electrodiffusive uptake mechanism. Am J Physiol 277(5 Pt 1):G976-G982

30. Bondzio A, Stumpff F et al (2008) Impact of Bacillus thuringiensis toxin Cry1 $\mathrm{Ab}$ on rumen epithelial cells (REC) - a new in vitro model for safety assessment of recombinant food compounds. Food Chem Toxicol 46(6):1976-1984

31. Stumpff F, Bondzio A et al (2007) Effects of the Bacillus thuringiensis toxin Cry1 $\mathrm{Ab}$ on membrane currents of isolated cells of the ruminal epithelium. J Membr Biol 219(1-3):37-47

32. Barry PH, Lynch JW (1991) Liquid junction potentials and small cell effects in patch-clamp analysis. J Membr Biol 121(2):101-117

33. Hille B (2001) Ion channels of excitable membranes, 3rd edn. Sinauer, Sunderland

34. Leonhard-Marek S, Stumpff F et al (2005) Basolateral $\mathrm{Mg} 2+/ \mathrm{Na}$ + exchange regulates apical nonselective cation channel in sheep rumen epithelium via cytosolic $\mathrm{Mg} 2+$. Am J Physiol Gastrointest Liver Physiol 288(4):G630-G645

35. Stumpff F, Strauss O et al (1997) Characterization of maxi-Kchannels in bovine trabecular meshwork and their activation by cyclic guanosine monophosphate. Invest Ophthalmol Vis Sci 38 (9):1883-1892

36. Colombini M (1989) Voltage gating in the mitochondrial channel, VDAC. J Membr Biol 111(2):103-111
37. Stumpff F, Martens H (2007) The rumen and potassium homeostasis: a model. Journal of Animal and Feed Sciences 16 (Suppl. 2):436-441

38. Droogmans G, Prenen J et al (1998) Voltage-dependent block of endothelial volume-regulated anion channels by calix[4]arenes. Am J Physiol 275(3 Pt 1):C646-C652

39. Helbig H, Korbmacher C et al (1989) Role of HCO3- in regulation of cytoplasmic $\mathrm{pH}$ in ciliary epithelial cells. Am J Physiol 257(4 Pt 1):C696-705

40. Bilk S (2008) Mechanismen der anionischen SCFA-Resorption im Pansen des Schafes. Thesis Univ Leipzig, Germany

41. Hisadome K, Koyama T et al (2002) Volume-regulated anion channels serve as an auto/paracrine nucleotide release pathway in aortic endothelial cells. J Gen Physiol 119(6):511-520

42. Manolopoulos VG, Voets T et al (1997) Swelling-activated efflux of taurine and other organic osmolytes in endothelial cells. Am J Physiol 273(1 Pt 1):C214-C222

43. Diener M, Scharrer E (1995) Swelling-activated conductances for chloride, potassium and amino acids in the rat colon: a whole-cell study. Exp Physiol 80(3):411-428

44. Diener M, Scharrer E (1994) The effect of short-chain fatty acids on $\mathrm{Cl}-$ and $\mathrm{K}+$ conductance in rat colonic crypts. Pflugers Arch 426(6):472-480

45. Hamodeh SA, Rehn M et al (2004) Mechanism of butyrateinduced hyperpolarization of cultured rat myenteric neurones. Neurogastroenterol Motil 16(5):597-604

46. Vidyasagar S, Barmeyer C et al (2005) Role of short-chain fatty acids in colonic $\mathrm{HCO}(3)$ secretion. Am J Physiol Gastrointest Liver Physiol 288(6):G1217-G1226

47. Zeissig S, Fromm A et al (2007) Butyrate induces intestinal sodium absorption via Sp3-mediated transcriptional up-regulation of epithelial sodium channels. Gastroenterology 132(1):236-248

48. Linsdell P (2001) Direct block of the cystic fibrosis transmembrane conductance regulator $\mathrm{Cl}(-)$ channel by butyrate and phenylbutyrate. Eur J Pharmacol 411(3):255-260

49. Qu Z, Hartzell HC (2000) Anion permeation in $\mathrm{Ca}(2+)$-activated $\mathrm{Cl}(-)$ channels. J Gen Physiol 116(6):825-844

50. Nilius B, Eggermont $J$ et al (2000) The endothelial volumeregulated anion channel, VRAC. Cell Physiol Biochem 10(56):313-320

51. Mitchell CH, Jacob TJ (1996) A nonselective high conductance channel in bovine pigmented ciliary epithelial cells. J Membr Biol 150(1):105-111

52. Valverde MA, Hardy SP et al (2002) Activation of Maxi $\mathrm{Cl}(-)$ channels by antiestrogens and phenothiazines in NIH3T3 fibroblasts. Steroids 67(6):439-445

53. Woll KH, Leibowitz MD et al (1987) A high-conductance anion channel in adult amphibian skeletal muscle. Pflugers Arch 410 (6):632-640

54. Schwiebert EM, Mills JW et al (1994) Actin-based cytoskeleton regulates a chloride channel and cell volume in a renal cortical collecting duct cell line. J Biol Chem 269(10):7081-7089

55. Blair KL, Geary TG et al (2003) Biophysical characterization of a large conductance anion channel in hypodermal membranes of the gastrointestinal nematode, Ascaris suum. Comp Biochem Physiol A Mol Integr Physiol 134(4):805-818

56. Bettendorff L, Kolb HA et al (1993) Thiamine triphosphate activates an anion channel of large unit conductance in neuroblastoma cells. J Membr Biol 136(3):281-288

57. Guibert B, Dermietzel R et al (1998) Large conductance channel in plasma membranes of astrocytic cells is functionally related to mitochondrial VDAC-channels. Int J Biochem Cell Biol 30 (3):379-391

58. Godbole A, Varghese J et al (2003) VDAC is a conserved element of death pathways in plant and animal systems. Biochim Biophys Acta 1642(1-2):87-96 
59. Komarov AG, Deng D et al (2005) New insights into the mechanism of permeation through large channels. Biophys J 89 (6):3950-3959

60. Forte M, Adelsberger-Mangan D et al (1987) Purification and characterization of the voltage-dependent anion channel from the outer mitochondrial membrane of yeast. J Membr Biol 99(1):65-72

61. Schweigel M, Park HS et al (2006) Characterization of the Na+dependent $\mathrm{Mg} 2+$ transport in sheep ruminal epithelial cells. Am J Physiol Gastrointest Liver Physiol 290(1):G56-G65

62. Graham C, Simmons NL (2005) Functional organization of the bovine rumen epithelium. Am J Physiol Regul Integr Comp Physiol 288(1):R173-R181

63. Ferreira HG, Harrison FA et al (1972) Ion transport across an isolated preparation of sheep rumen epithelium. J Physiol 222(1):77-93
64. Gäbel G, Vogler S et al (1991) Short-chain fatty acids and CO2 as regulators of $\mathrm{Na}+$ and $\mathrm{Cl}-$ absorption in isolated sheep rumen mucosa. J Comp Physiol [B] 161(4):419-426

65. Sehested J, Diernaes L et al (1996) Transport of sodium across the isolated bovine rumen epithelium: interaction with short-chain fatty acids, chloride and bicarbonate. Exp Physiol 81(1):79-94

66. Gäbel G, Bell M et al (1989) The effect of low mucosal $\mathrm{pH}$ on sodium and chloride movement across the isolated rumen mucosa of sheep. Q J Exp Physiol 74(1):35-44

67. Nagel W, Katz U (1997) Effects of NEM on voltage-activated chloride conductance in toad skin. J Membr Biol 159(2):127-135

68. Fatehi M, Linsdell P (2008) State-dependent access of anions to the cystic fibrosis transmembrane conductance regulator chloride channel pore. J Biol Chem 283(10):6102-6109 